DIW BERLIN

Discussion Papers

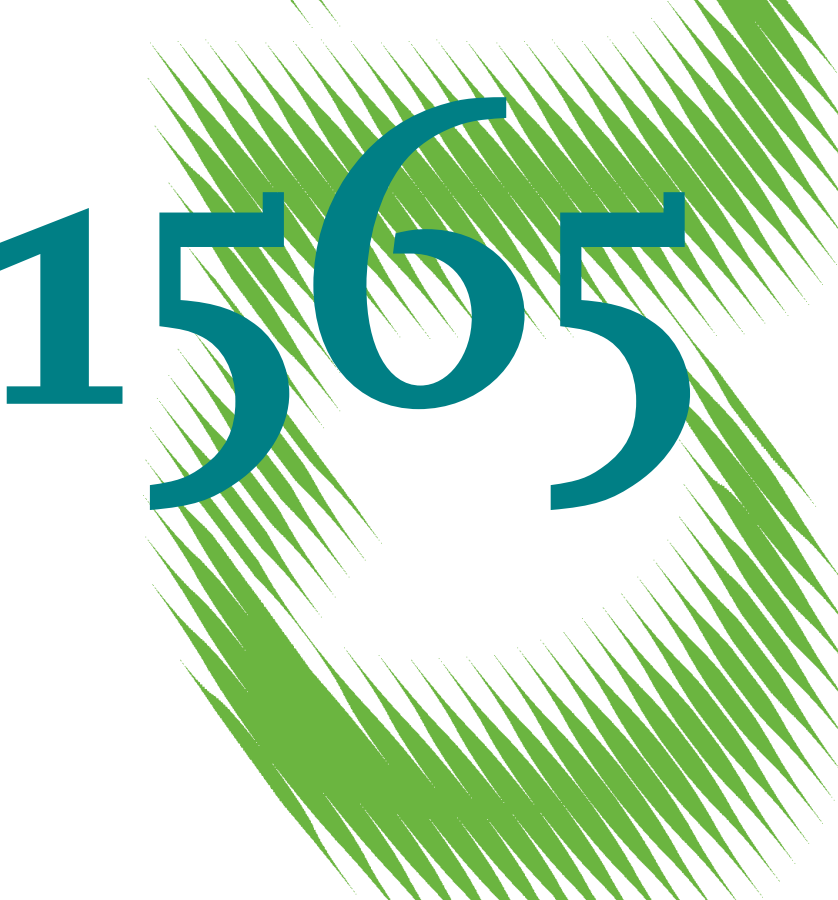

Bridging the Industrial Energy Efficiency Gap: Assessing the Evidence from the Italian White Certificate Scheme 
Opinions expressed in this paper are those of the author(s) and do not necessarily reflect views of the institute.

IMPRESSUM

(C) DIW Berlin, 2016

DIW Berlin

German Institute for Economic Research

Mohrenstr. 58

10117 Berlin

Tel. +49 (30) $89789-0$

Fax +49 (30) $89789-200$

http://www.diw.de

ISSN electronic edition 1619-4535

Papers can be downloaded free of charge from the DIW Berlin website:

http://www.diw.de/discussionpapers

Discussion Papers of DIW Berlin are indexed in RePEc and SSRN:

http://ideas.repec.org/s/diw/diwwpp.html

http://www.ssrn.com/link/DIW-Berlin-German-Inst-Econ-Res.html 


\title{
Bridging the Industrial Energy Efficiency Gap: Assessing the Evidence from the Italian White Certificate Scheme
}

\author{
Jan Stede*
}

\begin{abstract}
The Italian white certificate scheme is the main national policy instrument to incentivise energy efficiency of the industrial sector. The mechanism sets binding energy-saving targets on electricity and gas distributors with at least 50,000 clients and includes a voluntary opt-in model for participation from other parties. This paper investigates and assesses the elements of the scheme that help overcome several barriers to deliver industrial energy efficiency. Results from a survey conducted among leading experts indicate that the Italian system provides a strong financial incentive to energy efficiency investments, covering a significant share of investment costs and thus reducing payback time. Moreover, the scheme fosters the development of energy service companies (ESCOs), which are key to developing, installing and arranging finance for projects on the ground. In conjunction with other policies, the mechanism also raises awareness of energy efficiency investment opportunities, thus helping overcome the market failure of insufficient information. Core challenges remain, including tackling regulatory uncertainty and improving access to finance.
\end{abstract}

Keywords: White certificates, energy efficiency obligations, financial incentives, policy evaluation, ESCOs, industrial energy savings, market barriers

JEL codes: D22, D82, L14, L97, Q48

Acknowledgement: I am indebted to the experts that have made this paper possible by participating in the survey.

\footnotetext{
* German Institute for Economic Research (DIW Berlin), Climate Policy Department, Mohrenstr. 58, 10117 Berlin. +49 30 49789-484, jstede@diw.de.
} 



\section{Introduction}

Improving energy efficiency is one of the most cost effective ways to curb greenhouse gas emissions and improve energy security. The EU Energy Efficiency Directive (EED) sets a 20 per cent energy savings target by 2020 , and energy efficiency is one of the five dimensions of the EU's Energy Union Strategy (EC 2015). Despite being a central pillar of European energy and climate policy, many barriers have been found to prevent the implementation of an economically efficient level of energy efficiency investments.

The Italian white certificate scheme is an instrument designed and introduced to help overcome this 'energy efficiency gap'. Through energy efficiency obligations (EEOs) it imposes binding energy efficiency targets on obligated parties over a given period of time. Achieved savings are then credited with certificates, which can be traded on a market. Energy efficiency measures can potentially be carried out in all end-use sectors. Italy's 2014 National Energy Efficiency Action Plan (NEEAP) establishes the Italian white certificate mechanism as the main instrument to comply with the Energy Efficiency Directive (MiSE 2014). EEOs are also gaining importance across the EU - six European countries have already implemented energy efficiency obligations and ten others are planning their introduction (ENSPOL 2016, 2015).

In recent years, Italy has succeeded to shift the majority of energy efficiency measures within its white certificate scheme from the residential and tertiary sector to industry, a sector responsible for 25 per cent of EU final energy consumption (Eurostat 2014). Despite the economic downturn, Italy is still the EU's fourth largest economy and its second biggest manufacturing power. At the same time, Italy has the highest electricity prices of the major European economies and an energy dependency rate of more than 75 percent, well above European average (Eurostat 2015a). Consequently, improving competitiveness of the Italian industrial base through energy efficiency measures is an important national strategic priority.

The goal of this paper is to identify the factors that explain the success of the Italian white certificate scheme and to develop recommendations for other countries that consider introducing policies to address the energy efficiency gap. The analysis is primarily based on a survey conducted amongst leading experts during the annual conference on the Italian white certificates taken place in Rome on 19-20 March 2015. The survey highlights, first, a range of drivers incentivising industrial energy efficiency investments within the scheme, as well as remaining barriers. Moreover, it was possible to quantify the scale of the monetary incentive as the share of investment costs typically covered by white certificates and to identify the reduction in payback time of investment projects. A third focus is the role of energy service companies (ESCOs) in Italy. ESCOs are part of the energy services sector, which has so far achieved the majority of energy savings in the Italian white certificates mechanism.

The paper is structured as follows. Section 2 develops a taxonomy of barriers to industrial energy efficiency investments and illustrates the role the energy services sector can play to overcome the energy efficiency gap. Section 3 describes how white certificates systems work and analyses their implementation in Italy. Section 4 assesses the drivers for industrial energy efficiency investments in 
Italy, building on an analysis of the results of the survey carried out at the high-level conference in Rome. Section 5 develops policy recommendations and concludes.

\section{Barriers to industrial energy efficiency investments and the role of the energy services industry}

Past research has shown that the number of energy efficiency measures carried out is consistently below of what seems to be economically efficient, due to a range of different investment barriers (Thollander and Palm 2013). This phenomenon is known as the 'energy efficiency gap' (Jaffe and Stavins 1994).

\subsection{A taxonomy of barriers to industrial energy efficiency}

Sorrell et al. (2000 p. 11) define a barrier as "a postulated mechanism that inhibits investment in technologies that are both energy efficient and (apparently) economically efficient." This section develops a taxonomy of barriers to energy efficiency investments that are relevant in the Italian industrial sector. Table 1 presents an overview of the taxonomy, subdivided into the three categories financial, informational/behavioural/institutional and external.

Table 1: Taxonomy of barriers to industrial energy efficiency

\begin{tabular}{ll}
\hline Barrier & Explanation \\
\hline Short payback periods & $\begin{array}{l}\text { Firms do not carry out investments with payback times longer than } \\
2-5 \text { years due to risks associated with the investment }\end{array}$ \\
Limited access to capital & $\begin{array}{l}\text { Insufficient own capital (equity), access to external financing difficult } \\
\text { as banks are unwilling to lend }\end{array}$ \\
\hline Imperfect information & $\begin{array}{l}\text { Lack of credible information, e.g. due to search costs or low } \\
\text { trustworthiness of the information source } \\
\text { Lack of skilled }\end{array}$ \\
$\begin{array}{l}\text { Maintaining internal competences for energy management and } \\
\text { training personnel is costly } \\
\text { Low priority of energy } \\
\text { efficiency measures }\end{array}$ & $\begin{array}{l}\text { Organisations focus on core production activities, neglecting energy } \\
\text { efficiency investment opportunities (bounded rationality) }\end{array}$ \\
\hline Regulatory uncertainty & Ambiguities of existing regulation, undefined long-term policy goals \\
\hline
\end{tabular}

Source: Own illustration

Within financial barriers, the use of payback time as a relatively simple investment criterion is widespread among investors and lending institutions - in industry, payback times are generally below five years (IEA 2012). Short payback periods imply that only highly profitable projects are carried out and reflect uncertainty about market conditions in the medium term. For the Italian industrial sector, a survey among 115 companies that have carried out energy efficiency investments has revealed an average payback time of 2-3 years, constituting the main investment barrier (ES 2012). Moreover, difficult access to capital is among the major barriers to energy efficiency investments in the Italian industrial sector (EC JRC 2005; ES 2012). 
Energy efficiency investments may not take place due to imperfect information. Companies may lack sufficient information about energy efficiency opportunities due to search costs, especially small and medium-sized enterprises. 22 per cent of the Italian businesses interviewed by Energy \& Strategy Group have had difficulties to convince their top management to base investment choices on energy efficiency criteria because of insufficient knowledge about investment opportunities (ES 2012). Information may also be imperfect due to a low quality of the information source (Sorrell et al. 2000; Thollander and Palm 2013). In Italy, Trianni and Cagno (2012) find scarce and low-quality information to be among the primary investment barriers for Italian non-energy intensive SMEs. The shortage of adequate information is also caused by a lack of skilled personnel. In the Italian government's 2013 "National Energy Strategy" (Strategia Energetica Nazionale, SNE), the scarce availability of internal expertise and skilled personnel needed for complex efficiency measures are mentioned as principal barriers to energy efficiency in the industrial sector (MiSE and MATTM 2013). Finally, a low priority of energy efficiency measures, reflected in a strong focus on core production activities, has been found to be a relevant barrier to energy efficiency investments. In Italy, 25 per cent of businesses do not attribute strategic importance to energy management. This number rises to 40 per cent when only SMEs are considered (ES 2012). Similarly, Trianni et al. (2013) and Cagno and Trianni (2014) find that different investment priorities are the main barrier to energy efficiency investments for Italian SMEs.

The barrier of regulatory uncertainty - an ambiguous regulatory environment or undefined long-term policy goals, for example - raises the implicit discount rates of energy efficiency investments due to an increased riskiness (Schleich 2009). Regulatory uncertainty thus increases a focus on short-term projects and may deter potential beneficiaries of an energy efficiency incentive scheme from participating in the mechanism. In a recent survey among 161 Italian businesses from the Italian energy efficiency industry, a clarity of norms and a reduction of bureaucracy have emerged as the two most important investment drivers (ENEA 2015).

\subsection{The energy services industry}

The energy services industry, in particular energy service companies (ESCOs), is hailed by many experts as a promising means of overcoming many of the barriers to industrial energy efficiency (e.g. Sorrell et al. 2000). In Italy, the vast majority of savings under the white certificate scheme since 2005 have been delivered by so-called energy service provider companies (ESPCs) and ESCOs (see section 3.3).

Energy service contracting involves the outsourcing of energy services ${ }^{1}$ to a third party (Sorrell 2007). This third party, the energy service provider (ESP), is defined in Article 1 (24) of the EU EED as a "natural or legal person who delivers energy services or other energy efficiency improvement measures in a final customer's facility or premises" (EP 2012). This fairly general definition encompasses several types of actors (see Figure 1).

\footnotetext{
1 The term energy service is relatively new (Backlund and Thollander 2011). The first common definition was established by the European standard EN 15900:2010, where an energy service is defined as an operation to measurably improve energy efficiency, delivered on the basis of a contract.
} 


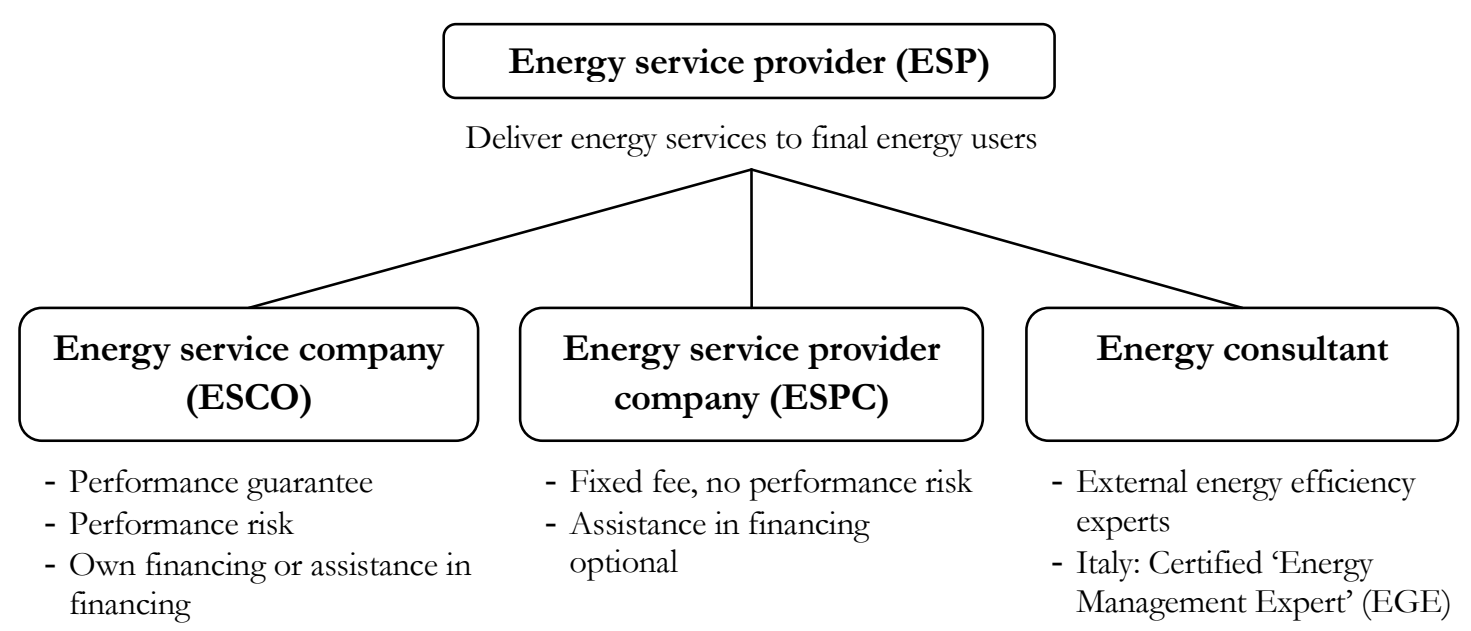

Source: Own illustration

Energy service companies (ESCOs) are frequently named as the type of energy service providers most capable of bridging the energy efficiency gap. Energy service companies have three main characteristics (Bertoldi et al. 2006):

- ESCOs carry out energy efficiency improvement measures (e.g. installation of new energy conversion equipment), and guarantee either a particular amount of energy savings or the same level of services from energy at lower cost (performance guarantee).

- Their remuneration is tied to the achievement of the contractually agreed energy savings, i.e. ESCOs accept an (equipment) performance risk.

- ESCOs finance the intervention themselves, or assist the customer in financing by providing a savings guarantee, thus accepting some degree of financial risk.

Consequently, ESCOs have a strong incentive to improve energy efficiency. The performancebased remuneration of ESCOs is reflected in so-called energy performance contracts (EPCs) ${ }^{2}$.

A company may also provide the same services as an ESCO, but not be penalized in the case of underperformance, and without accepting any financial risk (Hansen et al. 2009). Such an organisation is referred to as an energy service provider company (ESPC, see Bertoldi et al. 2006). ESPCs differ from ESCOs in the following ways:

- ESPCs charge a fixed fee for their service, without assuming any performance risk.

- ESPCs do not necessarily assist in financing their interventions.

Due to the lack of a performance guarantee, energy service provider companies have a smaller incentive than ESCOs to reduce their client's energy consumption. Nonetheless, these firms represent a significant fraction of the energy service providers in Europe (Backlund and

\footnotetext{
${ }^{2}$ In an energy performance contract, the ESCO guarantees a certain level of energy efficiency improvement, measured against a predetermined baseline. The ESCO's remuneration is tied to the achievement of the agreed level of savings this performance guarantee is at the heart of an EPC and implies a transfer of technical performance risk from the client to the ESCO (EC JRC 2014; Bertoldi et al. 2006).
} 
Thollander 2011). In Italy, ESPCs have dominated the energy services market in the past (Bertoldi et al. 2006).

Finally, energy service providers can also be external energy consultants. These are energy efficiency experts that advise companies on energy efficiency investments or carry out these investments on behalf of the client. Although no general definition exists for this type of actors, it is a relevant figure in the Italian context, where a certification for energy consultants as 'Energy Management Expert' (EGE) exists (see section 3.3).

Many of the barriers discussed above can be addressed by involving ESCOs or other energy service providers in the implementation of energy efficiency solutions. ESCOs that assist their customers in financing can help overcome capital shortages, addressing the barrier of limited access to capital. Moreover, ESCOs may bundle different measures in order to make the combined project size more attractive to lenders (Hansen et al. 2009). As energy service providers (ESPs) specialise in energy efficiency measures, they can make use of their knowledge multiple times, which gives rise to economies of scale (Sorrell 2007). Hence, ESPs may address the barrier of short payback periods by increasing the economic viability of efficiency projects. Additionally, through outsourcing energy management firms can focus on their core business. This addresses the behavioural barrier of a low priority of energy efficiency measures (Sorrell et al. 2000). ${ }^{3}$ Finally, ESCOs can also help overcome informational and competence barriers, as it is their core competence to identify the most promising and cost-effective potential energy efficiency measures (Backlund and Thollander 2011; Bertoldi et al. 2013).

\section{White certificates in Italy}

An energy efficiency obligation (EEO) sets a mandatory energy-saving target that energy market actors have to meet by implementing energy-efficiency measures in predefined end-use sectors over a given period of time. When achieved energy savings are credited with certificates by an independent authority and the system is combined with a trading option, such EEO mechanisms are called white certificate schemes. ${ }^{4}$

\subsection{The economics of white certificates}

White certificates are a policy instrument that can help bridge the energy efficiency gap by jointly addressing several market failures and developing the energy services industry (Giraudet and Finon 2015). Barriers to energy efficiency are addressed through several channels. First, the monetary incentive stemming from the certificate value improves the profitability of energy efficiency investments. Second, a well-designed mechanism with credible long-term savings obligations creates a stable regulatory framework. Third, the impact of informational barriers is reduced, because the existence of such a policy incentive may increase the level of awareness of energy

\footnotetext{
${ }^{3}$ However, one major drawback of outsourcing energy management is the presence of transaction costs. Since transaction costs are not necessarily related to the volume of the contract, they are more significant for smaller projects (Thollander et al. 2013).

${ }^{4}$ Energy efficiency obligations are also known as 'energy saving obligations' (ESO) or 'supplier obligations'. The terms 'energy efficiency obligation' and 'white certificates' are often used interchangeably in the literature.
} 
efficiency investment opportunities amongst companies. Finally, a white certificate scheme can facilitate the development of an energy services sector.

White certificate schemes have five key elements (Bertoldi et al. 2010):

1) Establishing an energy-saving obligation on some category of market actors - these can be electricity and gas distributors (grid owners) or suppliers (retail companies);

2) an institutional infrastructure and processes such as measurement and verification $(\mathrm{M} \& \mathrm{~V})$ of savings to support the scheme and the market, for example by determining a baseline against which savings are measured and authorising that the savings are valid;

3) a trading mechanism and the certification of savings;

4) a cost recovery mechanism (when the obligated parties are distribution companies);

5) an enforcement mechanism imposing sanctions in the case of non-compliance.

White certificate schemes are market-based instruments, i.e. they combine an obligation with market signals. Unlike 'command-and-control' regulations, tradable permits - if well designed equalise marginal compliance costs across market actors by fostering competition among businesses to carry out efficiency measures where they are most economic. This allows the delivery of savings at minimum aggregate cost (Stavins 2003; Pavan 2012).

\subsection{The Italian white certificate scheme}

The rationale for the promotion of energy efficiency can be energy security, addressing energy poverty, promoting economic growth or carbon abatement with little associated cost or risk (Grubb et al. 2014). The Italian energy system is characterised by industrial energy prices that are around 40 per cent above the EU average and more than 2.5 times as high as in Sweden, which currently has the lowest industrial electricity prices in Europe (Eurostat 2015b). ${ }^{5}$ Despite this, Italy is the EU's second biggest manufacturer and its fourth largest economy (The Economist 2013). Italy also has a level of energy dependency ${ }^{6}$ of more than 75 per cent, well above the European average of around 50 per cent (Eurostat 2015a). Consequently, improving energy efficiency to curb energy prices, enhance energy security and reduce carbon emissions cost-effectively is the most important priority named in the Italian government's 2013 National Energy Strategy (MiSE and MATTM 2013). Promoting energy efficiency is also seen as an opportunity to strengthen the energy services industry, in particular ESCOs, hence fostering economic growth by developing a 'green' supply chain (Di Santo et al. 2014; MiSE and MAT'TM 2013). In the 2014 National Energy Efficiency Action Plan (NEEAP), the Italian white certificate obligation is named as the main instrument to comply with the Energy Efficiency Directive (2012/27/EU), covering 60 per cent of the cumulative national 2020 target $^{7}$ (MiSE 2014). The industrial sector is at the heart of the Italian white certificate scheme - it is expected to deliver 94 per cent of the energy savings up to 2020.

\footnotetext{
5 The numbers refer to electricity prices for industrial consumers with a medium standard industrial consumption band of 500-2500 MWh. Prices correspond to the basic price and non-deductible taxes and levies; value-added tax (VAT) and other recoverable taxes and levies are therefore excluded.

${ }^{6}$ The energy dependency rate is defined as the percentage of net imports in gross inland consumption and fuel supplied to international maritime bunkers (Eurostat 2015a).

7 The EU Energy Efficiency Directive sets an annual savings target of 1.5 per cent of final energy consumption between 2014 and 2020 (EP 2012).
} 
Introduced in January 2005, the Italian white certificate system is currently in its third obligation phase (2013-2016). The energy savings targets in the Italian EEO scheme are defined in primary energy (toe) and converted into a corresponding number of certificates. This energy saving obligation is imposed on electricity and gas distributors with at least 50,000 clients. The actual energy efficiency measures, however, can also be delivered by third parties. This approach can help to foster the growth of the energy services market (Bertoldi et al. 2010). Eligible third parties include energy service providers such as ESCOs or ESPCs (called società di serviz̨i energetici, SSE), companies that have nominated an 'Energy Manager' (see section 3.3), companies that have a certified 'energy management system' ISO $50001^{8}$ in place and smaller distributors with less than 50,000 clients.

Once a project is accepted, white certificates are awarded annually for a period of five years (ENEA 2014). These certificates can then be traded, either on the spot market or bilaterally. The electricity and gas distributers get a reimbursement (cost recovery) for their expenses, which is financed by the electricity and natural gas tariffs. Sanctions are imposed in the case of noncompliance $^{9}$ (ENEA 2014).

\subsubsection{Methods of saving and additionality}

In the Italian white certificate system, a wide range of energy efficiency projects is possible. There are four different methods to acquire white certificates, namely deemed savings, simplified monitoring projects, monitoring plans and Major Projects. Energy efficiency projects are possible in all end-use sectors (industry, public, residential, tertiary, transport, agriculture). ${ }^{10}$

In the deemed savings approach (metodo di valutazione standardizzata) actual savings do not have to be measured, as the method relies exclusively on ex ante calculations. This makes it suitable for standardised projects in the residential or public sector. Efficiency interventions are chosen out of a predefined list of available measures, the so-called 'technical data sheets' (schede tecniche). The algorithms to determine the amount of energy savings for the different interventions described in the technical data sheets also account automatically for additionality and corrective factors, such as geographical location and climatic factors (Di Santo et al. 2014). Deemed savings projects have a minimum size of 20 toe per year.

The other methods of saving all rely - albeit to varying degrees - on the metering approach ${ }^{11}$. As in the case of deemed savings projects, simplified monitoring (metodo di valutazione analitica) projects use standardised technical data sheets. However, energy consumption has to be monitored

\footnotetext{
8 The international norm ISO 50001 issued in 2011 defines the minimum requirements for an energy management system. These include an energy audit, the formulation of energy savings goals and the implementation and verification of these goals. The system is not widespread in Italy (ES 2012).

${ }^{9}$ The compliance period (anno d'obbligo) for a given year is from 1 June of that year to 31 May of the following year. In order not to incur sanctions, obligated parties must reach at least 50 per cent of their yearly target in that same year and fulfil the entire obligation within two years (AEEGSI 2014).

${ }^{10}$ In the proposal for new 'guidelines" (linee guida) for the white certificate scheme that has been released for public consultation in the autumn of 2015, the Italian Ministry of Economic Development has outlined a new fifth method of saving. The motivation is to foster the development of energy efficiency measures in sectors that have not seen a lot of projects so far, such as the transport sector (MiSE and MATTM 2015).

${ }^{11}$ As an alternative to the deemed savings approach, in the metering approach energy consumption is monitored on an individual basis (Lees 2012).
} 
while the project is carried out to determine the overall amount of energy savings. ${ }^{12}$ As a result, certificates are not awarded automatically, but depend on the actual amount of energy saved in each of the five years for which certificates are emitted. The minimum threshold for a simplified monitoring project is 40 toe of annual savings.

Monitoring plans (metodo di valutazione a consuntivo) are the most complex of the three major savings methods. They are chosen for projects where no deemed savings or simplified monitoring data sheets exist, i.e. for more complex and structural projects. The scope of this savings method is wide - any energy efficiency measure within the range of eligible project types can potentially be proposed using the monitoring plans methodology. To determine the baseline on which to award white certificates, the energy consumption is measured prior to the energy efficiency intervention. After its implementation, actual energy savings are also measured and monitored on-site (ENEA 2014). Before actually requesting white certificates within the monitoring plans method, the interested party has to present a proposal describing the project and the savings calculation called Proposta di Progetto e Programma di misura (PPPM). ${ }^{13}$ Monitoring plans are especially suitable for industry due to their large minimum project size of 60 toe and the limited availability of technical data sheets for deemed savings and simplified monitoring projects in that sector (ENEA 2013).

The so-called Major Projects (grandi progetti) are a relatively new method to acquire white certificates, introduced by the ministerial decree 28 dicembre 2012 (DM 28/12/12, MiSE and MATTM 2012). These projects are intended for large infrastructure measures, industrial processes or the transport sector. The minimum requirement is a project size of 35.000 toe of savings per year and a lifetime of at least 20 years. Major Projects benefit from significant uplift factors ${ }^{14}$ and can be guaranteed a fixed white certificate price (ENEA 2014; GSE 2014a).

The Italian white certificate scheme accounts for additionality ${ }^{15}$ of energy efficiency measures by defining a market and regulatory baseline for each technology. To construct this baseline, the average performance of the technology on the market, as well as expected technological progress, minimum legal requirements (such as maximum consumption standards) and ex ante consumption (situation prior to the intervention) are taken into account (ENEA 2014; FIRE 2014). Only efforts that go beyond this baseline are awarded white certificates. There is typically full or at least high additionality in the industrial sector (Di Santo et al. 2014) - in other words, the financial incentive of the Italian white certificate system is especially pronounced in industry.

\footnotetext{
12 An example of such a project is the substitution of natural gas with biomethane in public transport.

13 This PPPM describes the energy efficiency intervention, identifies the baseline to estimate additionality, defines the energy savings calculation algorithm and describes the M\&V system (Di Santo et al. 2014).

${ }^{14}$ Uplift factors are an instrument to promote technological change. Energy savings resulting from energy efficiency measures are multiplied with the corresponding uplift factor, granting additional savings that improve the economic viability of the investment. Depending on the degree of innovation and the size of the project, Major Projects can be granted uplift factors of up to 50 per cent (GSE 2014a).

15 The idea of additionality is to count and reward only energy efficiency improvements that would not have occurred without the policy intervention, for example because of technological progress or stricter regulatory standards (Ecofys 2012). The degree of additionality is a decisive factor in determining the economic viability of an energy efficiency intervention.
} 


\subsubsection{The tau coefficient}

The introduction of the tau coefficient $(\tau)$ in January $2012^{16}$ has led to a drastic transformation of the Italian system by significantly improving the economic value of white certificates for an energy efficiency project, especially in the industrial sector. The tan coefficient is a multiplier that awards additional white certificates for an energy efficiency measure by remunerating future (discounted) savings over the entire technical lifetime. The concept is illustrated by Figure 2. The blue bars represent the certificates that were awarded prior to the introduction of $\tau$. Since the introduction of tau, further savings are discounted ${ }^{17}$ with a rate of two per cent (orange bars from year six onwards) and added to the savings awarded in the first five years. Taking the example of an intervention with a technical lifetime of 20 years that is typical in the industrial sector (e.g. heat recovery in an industrial process), this leads to a $\tau$ multiplier of $3.36 .{ }^{18}$

Figure 2: Illustration of the tau coefficient

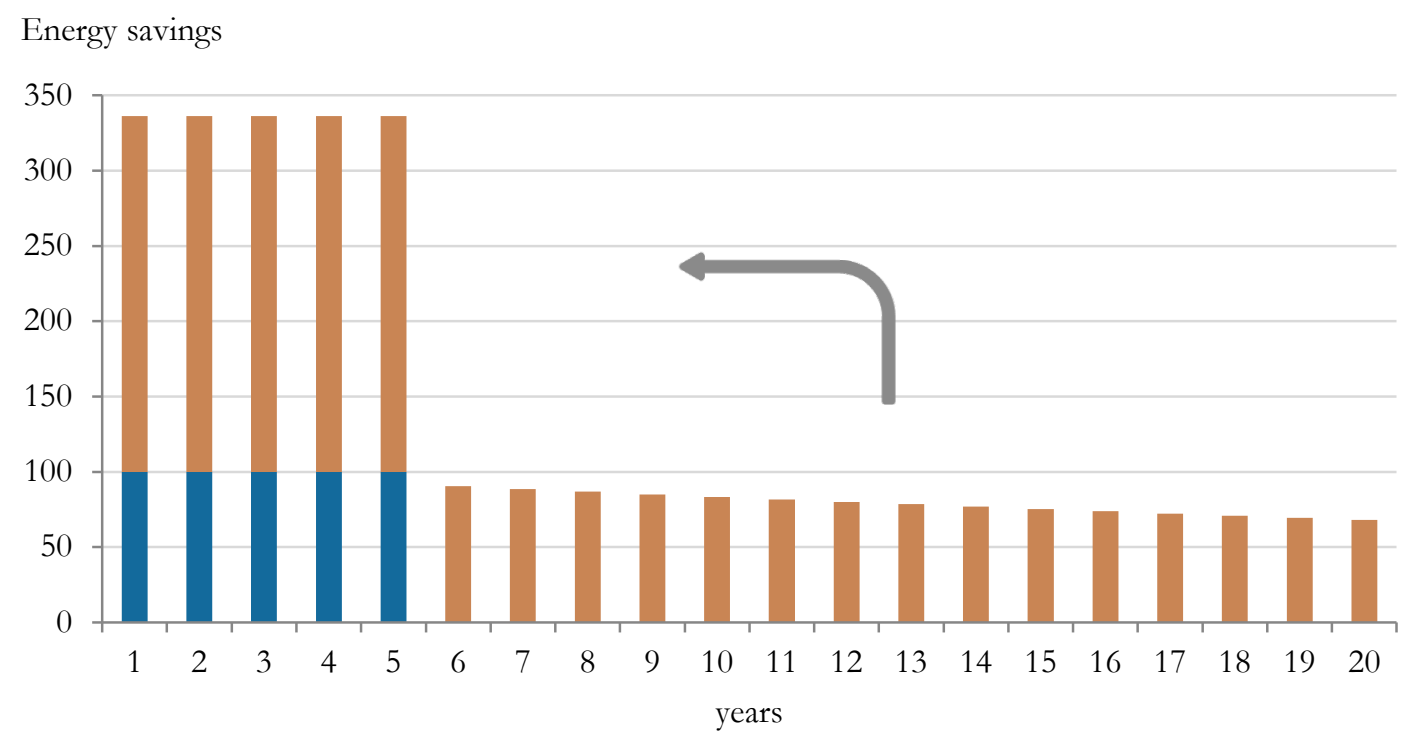

Source: Adapted from Di Santo et al. (2014)

Hence, the tau multiplier incentivises projects with a long lifetime and corrects the concept of technology-neutrality, which had penalised more structural measures with higher capital costs in the industrial sector before. The rationale behind the introduction of tau is that such projects need a stronger financial incentive to be economically viable.

\subsubsection{Evolution of the Italian white certificate scheme}

The Italian EEO scheme has seen a drastic transformation of the types of projects implemented, away from the 'civil' sector (residential, tertiary and agriculture) towards projects in industry (see Figure 3). Compact fluorescent lamps (CFLs) in the residential sector in particular dominated the

\footnotetext{
16 The tan coefficient was introduced, among other structural measures, by the Italian energy market regulator AEEGSI's 2011 resolution 'delibera EEN 9/11' (also called 'guidelines' or linee guida) (AEEG 2012a).

${ }_{17}$ The magnitude of the discount factor is an important determinant of the cost of compliance with the energy saving goals imposed by a white certificate scheme. Discounting future electricity savings may happen either for economic reasons - as an expression of economic time preference - or may reflect a loss of efficiency due to aging of technical equipment. (Bertoldi et al. 2010).

${ }^{18}$ Depending on the technical lifetime of the intervention (between five and 30 years), tau takes on values between 1.00 and 4.58. In industry, it is typically 3.36 .
} 
Italian white certificate system in its early years - CFLs accounted for 50 per cent of the cumulative savings between 2005 and 2010, and their share of annual savings was as high as 60 per cent in 2007 and 2008. In order to address additionality concerns, the energy market regulator AEEGSI gradually tightened the eligibility criteria for CFLs, until their complete exemption from the white certificate scheme in February 2011 (AEEG 2011a). ${ }^{19}$ The share of certificate emissions from industry, on the other hand, has risen from six per cent in 2007 to 62 per cent in 2015. In 2013 and 2014 it was as high as 80 per cent. ${ }^{20}$ The first Major Project - 25 high-speed trains of the Italian railway company Italo-NTV - has also started to generate savings in 2015, accounting for 2.6 per cent of annual emissions. ${ }^{21}$

Figure 3: Share of annual white certificate emissions by sector

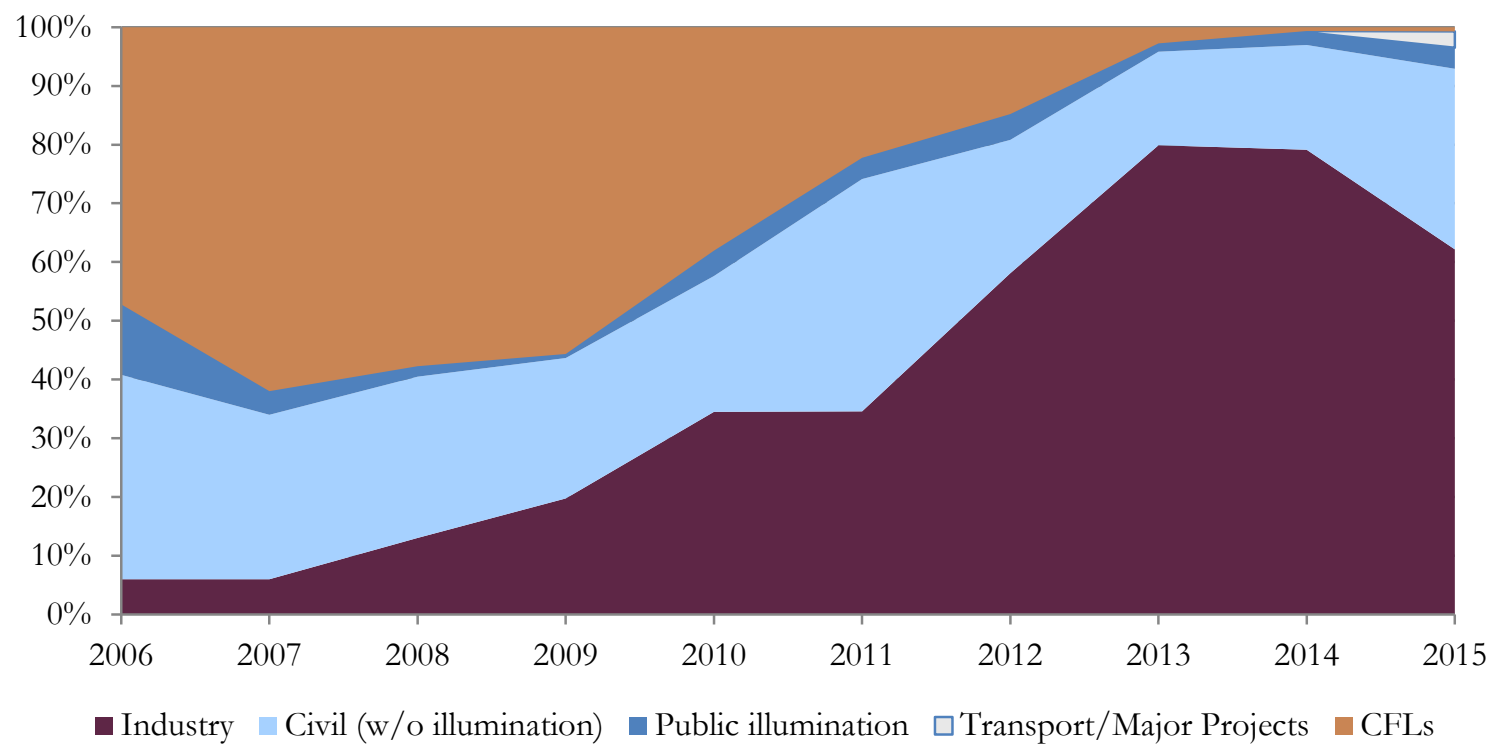

Source: Own illustration based on calculations using data from AEEG (2006, 2007, 2008, 2009a, 2009b, 2009c, 2010a, 2010b, 2011a, 2011b, 2011c, 2012b, 2012a, 2012c) and GSE (2014a, 2015, 2016) $)^{22}$

The increase of projects from the industrial sector is mirrored in the share of certificate emissions by method of saving. The early years of the Italian white certificate scheme were dominated by deemed savings projects, accounting for 75 to 90 per cent of annual savings in the period 20062010. In recent years, savings from the more challenging monitoring plans usually applied in the industrial sector have risen to shares between 64 and 80 per cent (calculated from GSE 2016).

\footnotetext{
${ }^{19}$ CFLs were considered fully additional in the beginning of the white certificate scheme. Between 2005 and 2011, a total of almost 75 million CFLs were distributed through the Italian white certificate system (AEEG 2012a). Whether the massive give-aways of CFLs which led to such high numbers actually resulted in corresponding high energy savings is questionable (Bertoldi et al. 2010).

${ }^{20}$ The predominant industrial sectors in 2013 and 2014 have been paper, glass \& iron and steel. Typical projects were optimisation of production processes, plant layout, improvement of furnaces and thermal recovery of processes (Valenzano 2015).

${ }^{21}$ Italo-NTV is the second largest Italian railway company and state-owned Trenitalia's main competitor in the segment of high-speed trains. The project has been awarded an uplift factor of 5 per cent (GSE 2014b). Regarding the approval of NTV's proposal, there have been criticisms of state aid to NTV (Iannaccone 2015). When NTV ordered the trains in 2008, the possibility to apply for Major Projects did not even exist - this violates the materiality condition of the EU EED (Lees 2016).

${ }^{22}$ The shares of the years 2006-2010 refer to the obligation period of each year (June-May). Due to data limitations, the shares for 2011 and 2012 had to be approximated by the proportions of certificate emissions in June-December 2010 and January-May 2011, respectively. The 2013-2015 numbers refer to the respective calendrical years.
} 
The introduction of the tan coefficient has led to a surge of white certificate emissions and a corresponding stabilisation of the DSOs' compliance with their annual targets. These effects are visible in Figure 4, which plots the development of the white certificate obligation and the total number of certificates emitted in the years 2006-2015 (left scale), as well as the number of white certificates issued since the beginning of the scheme relative to the cumulative savings obligation assigned to all electricity and gas DSOs for each year ("target compliance"23, right scale).

Figure 4: Development of the white certificate obligation and compliance with the annual targets

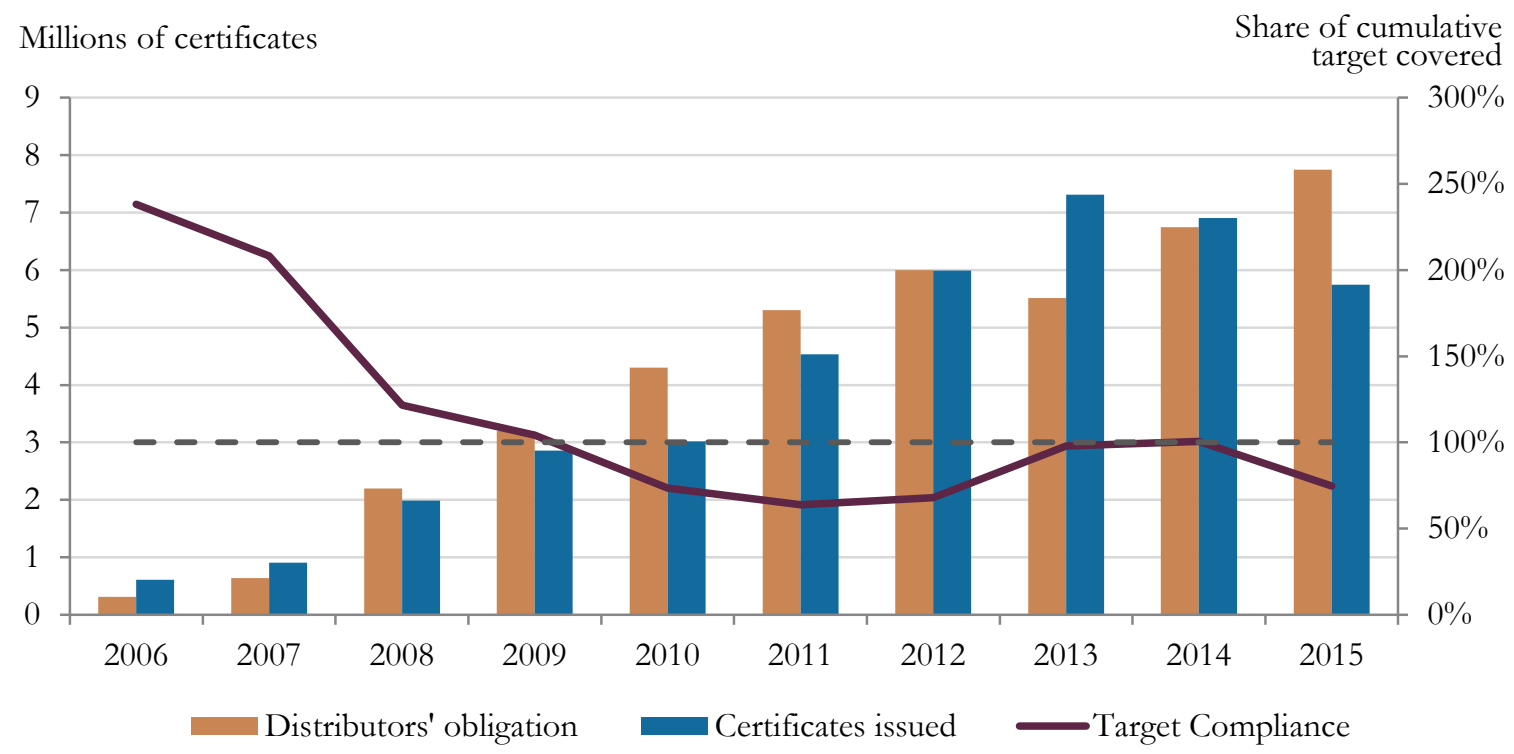

Source: Own illustration based on calculations using data from GSE (2016), ENEA (2011), DM 28/12/12, AEEG (2007, 2008, 2009a, 2011a, 2012c) and GME (2011, 2012a, 2012b, 2013a, 2013b, 2014a, 2014b, 2015a, 2015b, 2016) ${ }^{24}$

Since the introduction of the Italian white certificate scheme, the annual primary energy savings targets have risen steadily. ${ }^{25}$ Figure 4 shows that the introduction of the tau coefficient has helped to meet these increasing energy efficiency targets - in the 2012 obligation period almost 1.5 million additional certificates have been issued with respect to the previous year. In addition, regulatory changes introduced by the ministerial decree DM 28/12/12 have significantly influenced certificate emissions in the years 2013 to 2015 (GSE 2016). ${ }^{26}$ Prior to the introduction of tau, target compliance had decreased continuously until its low of 64 per cent in 2011, reflecting the inability of the system to meet rising energy savings obligations in the absence of low-hanging fruit such as

\footnotetext{
${ }^{23}$ Target compliance includes the surplus or deficit of certificates accumulated in previous years. A compliance above 100 per cent does not necessarily imply that all operators have complied with their individual obligations.

24 The years shown in Figure 4 refer to the respective obligation period (anno d'obbligo), which extends from 1 June of any year to 31 May of the following year.

25 The only exception is the year 2013, where the primary energy savings goal decreased to 4.6 Mtoe. In 2014, it was raised again to 6.2 Mtoe (MiSE 2014), an increase of almost 35 per cent. Until the end of 2011, one certificate was equal to one tonne of oil equivalent of primary energy. Since the introduction of the tau coefficient, the primary energy goals are converted into white certificates assuming an average national tau coefficient of 2.5 (MiSE and MATTM 2012). Consequently, certificate emissions depicted in Figure 4 before and after 2011 are not directly comparable with respect to the underlying primary energy savings.

${ }^{26} \mathrm{DM}$ 28/12/12 has introduced two important novelties. First, since mid-2013 white certificates cannot be cumulated anymore with other state incentives, such as feed-in tariffs or tax cuts. This has contributed to the one-time effect of a leap of certificate emissions to benefit from the additional financial incentives prior to their abolishment, followed by a subsequent decrease in the presentation of projects. Second, since 2014 white certificates can only be claimed for new projects or projects that are in their realisation phase. This has led to a drop of emissions in 2014 and 2015 (GSE 2016).
} 
CFLs (FIRE 2015; Romano 2013). Increased energy savings due to a higher number of projects in the years 2012-2015 have reversed this trend, with target compliance peaking at 100 per cent in 2013 and 2014. However, because the energy savings obligation is also rising, target compliance is projected to decrease to 77 per cent in the 2015 obligation period, which ends on 31 May 2016.

\subsection{Energy services in Italy}

Despite the many advantages of the ESCO solution in combination with energy performance contracting the concept is still not very widespread in Europe, even in the energy-intensive industry (Thollander et al. 2013). The Italian energy services sector is considered one of the more developed European markets. It has long remained stable, without being particularly large (EC JRC 2014; Hansen 2006). The actual size of the market and the number of genuine ESCOs operating in the market, has however, been subject to continued debate.

The vast majority of energy savings in the Italian white certificate scheme have been delivered by the so-called 'Energy Service Businesses' (societá di serviz̨i energetici, SSE). These businesses can be ESCOs, if they meet the criteria discussed in section 2.2; otherwise they are energy service provider companies (ESPCs). ${ }^{27}$ The Italian legislator has obligated Energy Service Businesses that apply for white certificates to be in possession of the Italian UNI CEI 11352 ESCO certification by July $2016{ }^{28}$ The goal is to enhance the quality of the Italian energy services market and foster the development of SSE into 'real' ESCOs. There has been a dynamic growth of certified ESCOs in recent years. Their number has been estimated at 27 in 2012 (ES 2012), 49 as of 2013 (EC JRC 2014), 116 in 2014 (EnergyINlink 2014), and has risen to at least 143 by early 2016 (FIRE 2016).

Firms that have nominated a so-called 'Energy Manager' can also directly apply for white certificates. Energy-intensive Italian companies have been obliged to nominate a "technician responsible for the conservation and rational use of energy" (Legge 10 1991) since the early 1990s. ${ }^{29}$ There are currently around 3,000 Energy Managers in Italy; half of these are named voluntarily and about 500 work in industry (Giliberto 2015). Energy Managers will have to be in possession of the certification as an Energy Management Expert (EGE) $)^{30}$ in order to be eligible for white certificate projects starting from July 2016. Hence, the number of Energy Management Experts, which was estimated at 30 in the industrial sector at the end of 2012 (ES 2012), is bound

\footnotetext{
${ }^{27}$ The SSE are often erroneously called ESCOs (or call themselves ESCOs), but are simply defined as companies that describe the realisation and subsequent management of energy efficiency measures as one of their business goals (AEEG 2011d). Moreover, neither any previous experience in the energy efficiency business nor specific competences are necessary to register as an SSE (Ancora 2013).

${ }^{28}$ This obligation was introduced by the legislative decree D.Lgs. 102/2014 (Consiglio dei Ministri 2014). UNI CEI 11352 is a recent norm, dating back to 2010. Since its revision in 2014, in order to qualify for the certification ESCOs need to have carried out at least one EPC (Belcastro 2014).

29 Article 19 of 'legge 10/91' introduces the obligation to nominate an Energy Manager for all companies with a consumption of more than 10,000 toe for firms in the industrial sector, and 1,000 toe in other sectors. The Energy Manager can either be an employee or an external consultant.

30 'Energy Managers' are often confused with 'Energy Management Experts', although the former is an operative function, whereas the latter is a professional qualification. 'Energy Management Experts' (Esperti in Gestione dell'Energia, EGE) are energy consultants that possess a certification according to the norm UNI CEI 11339. Energy Management Experts cannot obtain white certificates themselves, but can assist larger companies in acquiring white certificates by carrying out an energy audit, for example (see Art. 8 of D.Lgs. 102/2014). Moreover, ESCOs certified according to the norm UNI CEI 11352 need to have at least one Energy Management Expert in their company. In the certification of EGE, experience plays a fundamental role. Depending on their university degree, certified Energy Management Experts need to have three to ten years of professional working experience (ES 2012).
} 
to rise. Moreover, Energy Managers can be expected to build up additional competences during the EGE certification process.

Figure 5 graphs the shares of white certificates obtained by different market actors. Energy Service Businesses have acquired a relatively stable average share of around 75 per cent of the total white certificates emitted since the introduction of the scheme. The share of companies with an Energy Manager has grown from around five per cent in 2010 and 2011 to 25 per cent in 2013 and 2014. ${ }^{31}$

Figure 5: Share of white certificates by type of party

Percentage of cumulated certificate emissions

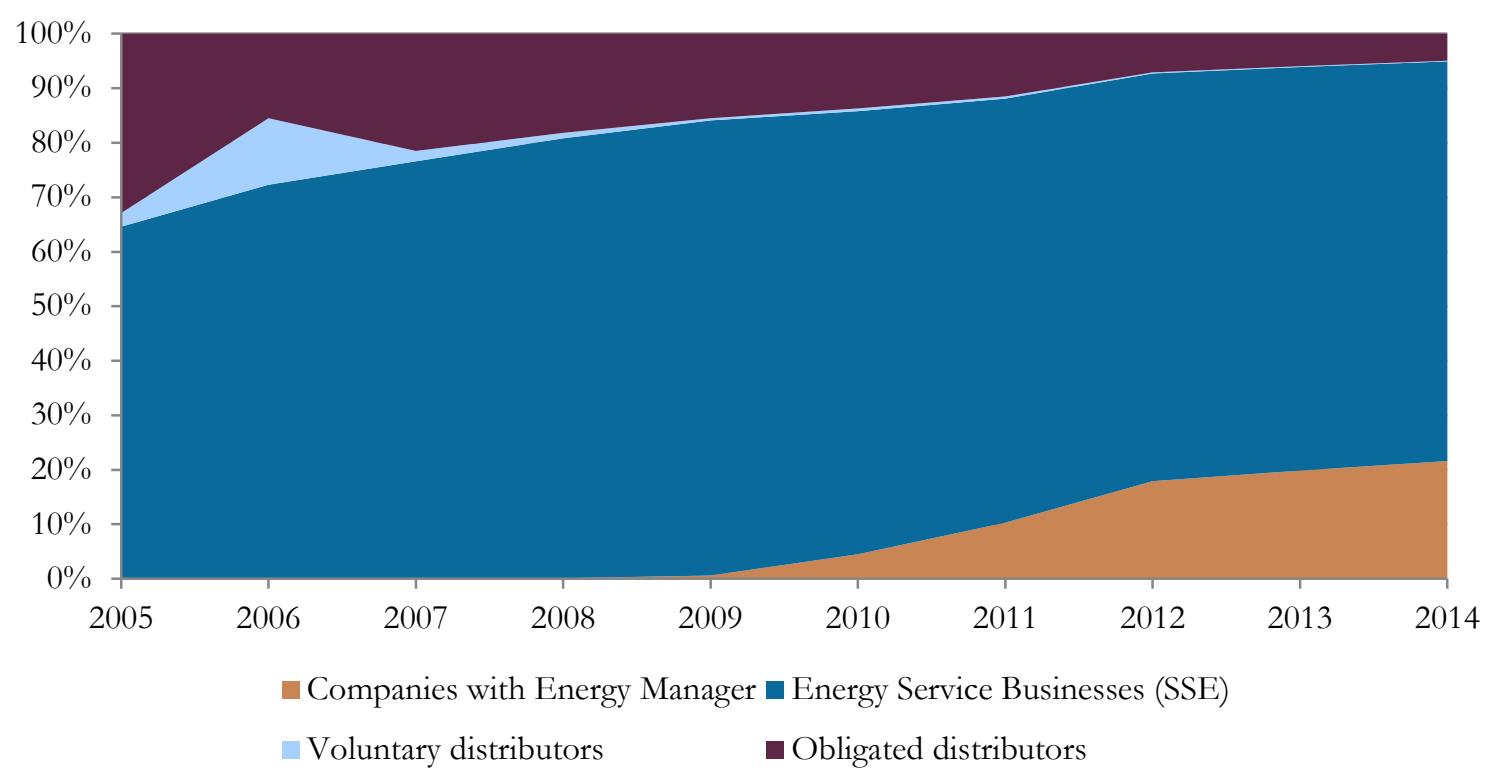

Source: Own illustration based on calculations using data from AEEG (2012a, 2012c), GME (2013b) and GSE $(2014 \mathrm{a}, 2015)^{32}$

\section{Industrial energy efficiency investments in Italy - Results from the survey}

This section explores the principal drivers of industrial energy efficiency in Italy. The goal is to explain which of the barriers to industrial energy efficiency discussed in section 2.1 have been overcome, to explore the main drivers for the implementation of energy efficiency projects in the industrial sector (taking into account the role of the energy services sector in this process) and to highlight remaining challenges. The analysis draws primarily from a survey ${ }^{33}$ carried out by the author among speakers and other participants of the annual conference on white certificates in Italy organised by the Italian Federation for the Rational Use of Energy (FIRE) in Rome on 19-20 March 2015. As the leading experts on the scheme from the energy services industry, research

\footnotetext{
31 The possibility to apply for white certificates was introduced for companies with the obligation to name an Energy Manager in 2008. Since 2013, this possibility has been extended to companies that voluntarily name an Energy Manager.

32 Due to data restrictions, the 2012 shares are interpolated between 2011 and 2013. Moreover, 2005-2012 numbers refer to the annual obligation period (May-June), whereas 2013-2014 data represents the respective calendrical years.

33 The questionnaire used for the survey is available from the author on request.
} 
institutions and politics were among the participants of the conference, it represented a unique opportunity to interview the most relevant stakeholders.

The interviews were carried out in two steps. First, face-to-face interviews were conducted at the FIRE conference using a printed questionnaire, mainly targeting the speakers of the conference. ${ }^{34}$ Second, a digitalised version of the same questionnaire was sent via e-mail to those speakers of the conference who had not yet been interviewed. A total number of 16 people have completed either the printed or the online questionnaire. ${ }^{35}$ Ten of these respondents are conference speakers, implying that the survey covers 40 per cent of the 25 conference speakers.

\subsection{Drivers and barriers to industrial energy efficiency}

As expected, white certificates have emerged as the most important policy instrument to incentivise energy efficiency in the industrial sector. Interviewees were asked to name the three most important policy instruments in industry. To convert the responses into a meaningful ranking, the ranks are converted into numbers by assigning each rank 1,2 and 3 a corresponding score of 3,2 and 1. Factors that are not assigned any rank are awarded a score of zero. The scores given to each barrier are then averaged ${ }^{36}$, as illustrated in Figure 6.

White certificates were indicated by more than two out of three respondents as the most important policy instrument, with an average score of 2.5. Low-interest loans and guarantee funds - with an average score of 0.9 and 0.7 , respectively - are rated next. These two incentives can be combined with white certificates, which is not true for tax cuts and feed-in tariffs (FIRE 2015). The obligation to name an Energy Manager for large industrial companies, which exists since 1991, does not seem to have helped much to increase investments into energy efficiency.

\footnotetext{
${ }^{34}$ Speakers are assumed to have a greater knowledge of the Italian white certificate system than do 'normal' conference participants. Moreover, conference participants who had talked to speakers or seemed to know them were also preferred interview partners. Those attendees with a relation to the speakers can be expected not to be 'newcomers' in the Italian white certificate system and therefore have a more thorough knowledge of the scheme.

35 Seven interviewees come from the energy services industry - five ESCOs and one (non-certified) ESPC, as well as one self-employed Energy Management Expert (EGE). Three respondents belong to ESCO or industry associations. One respondent works at the Ministry of Economic Development, two in research organisations and three in other fields.

36 With this approach every barrier gets an average score between zero (if not chosen by anyone) and three (if everybody chooses one barrier as the most important one). The method assumes a common 'distance' of importance between any two consecutive ranks (Abeyasekera 2003).
} 
Figure 6: The major policy instruments to promote industrial energy efficiency

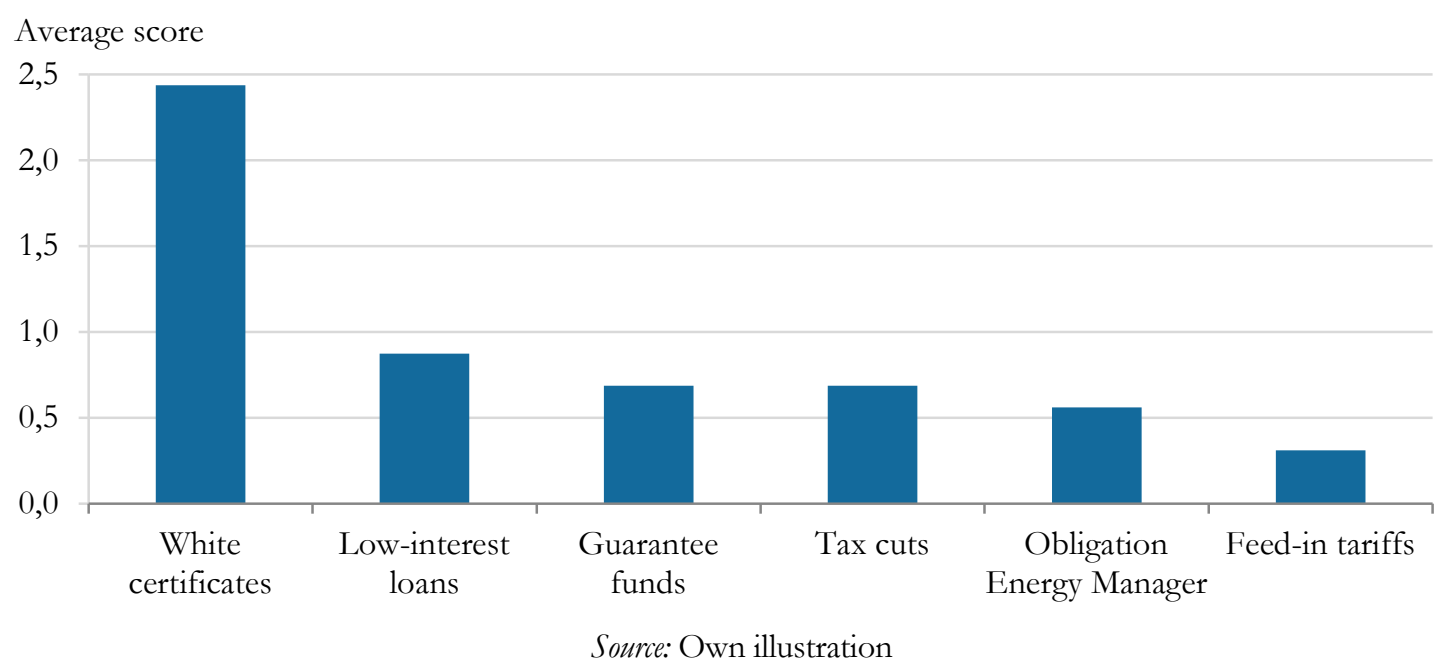

\subsubsection{Barriers to industrial energy efficiency}

The interviewees were asked to name the three most important barriers to investments in industrial energy efficiency projects involving white certificates. Figure 7 plots the results, evaluated with the same procedure of transferring ranks to average scores as above.

Figure 7: The main barriers to energy efficiency in the industrial sector

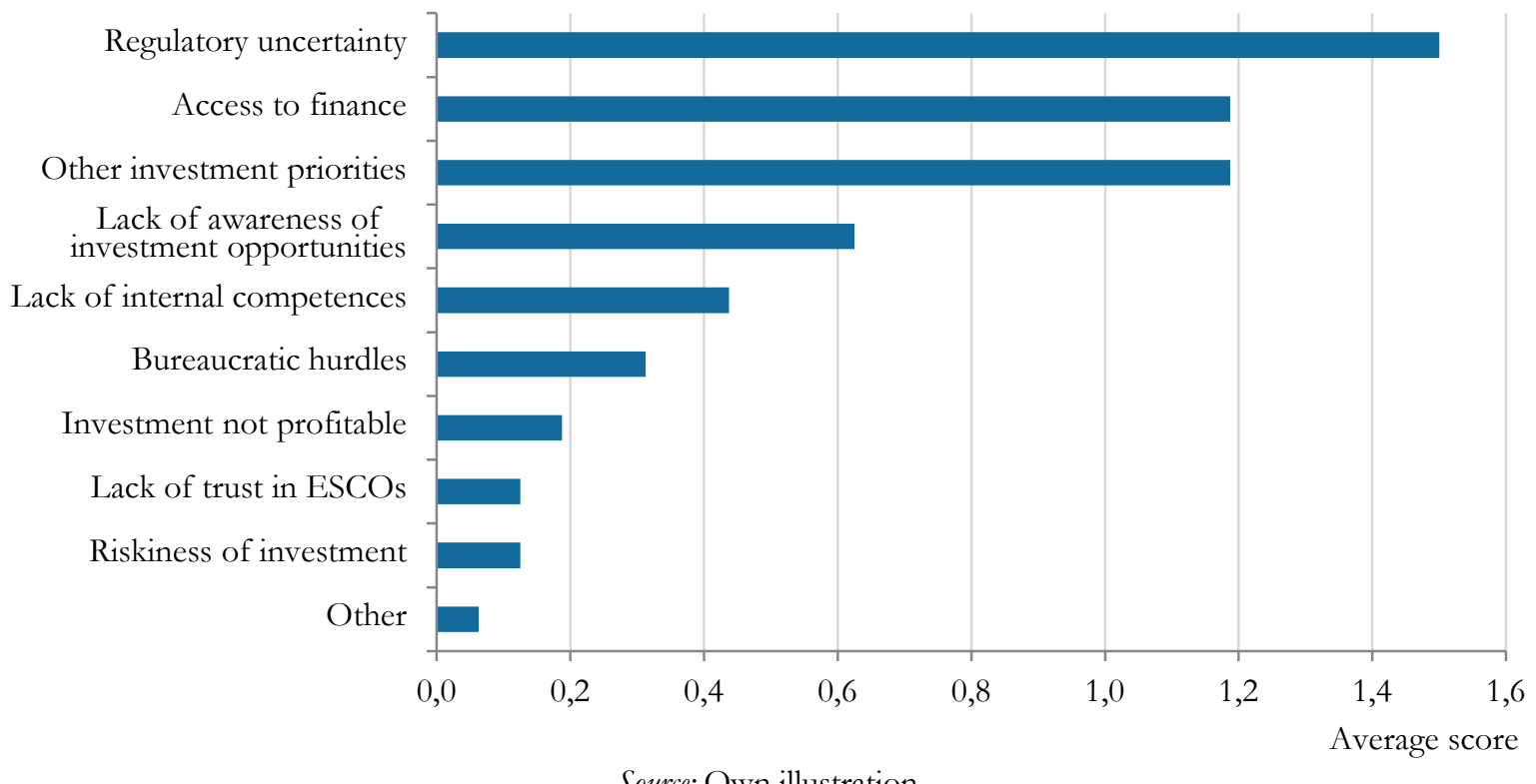

Source: Own illustration

Interestingly, regulatory uncertainty emerges as the most important barrier to industrial energy efficiency in Italy (average score of 1.5), named by one third of the respondents as the most important obstacle. Its relative importance within the Italian white certificate mechanism is probably not representative of the European energy efficiency industry in general, but is a particular characteristic of the Italian system. There are several manifestations of regulatory uncertainty in the Italian EEO. Binding energy efficiency goals for the 2013-2016 period, for example, were only formally adopted by the ministerial decree DM 28/12/12 in December 2012 less than half a year before the expiry of the previous targets. This implied major uncertainties 
about the economic value of white certificates in the medium term. ${ }^{37}$ Moreover, the absence of updated guidelines (linee guida) on the Italian white certificate scheme significantly aggravate regulatory uncertainty and hinders a further development of the Italian white certificate mechanism. The existing guidelines, which introduced the tau coefficient amongst other novelties, date back to 2011 (AEEG 2011d). Although the publication of updated guidelines has repeatedly been announced for years, at the time of writing renewed guidelines have still not been published. ${ }^{38}$ This remarkable delay means, for example, that the technical data sheets for deemed savings and simplified monitoring projects are not updated and new project types cannot be presented in a simplified, standardised manner. Instead, proponents mostly have to rely on the more demanding monitoring plans for new projects. As a result, significant efficiency gains are forgone. Moreover, several participants at the FIRE conference expressed their displeasure with the complicated bureaucratic process of obtaining white certificates. Thus, the management of the scheme by GSE seems to be unsatisfactory from the point of view of many operators. This also contributes to regulatory uncertainty, identified as the principal investment barrier in Figure 7.

The relative importance of other barriers to investments in industrial energy in the survey is in line with other research. The lack of an access to capital, rated the second most important barrier, is regularly named in empirical studies as one of the major barriers. Italian banks are often reluctant to lend for energy efficiency investments. ${ }^{39}$ One reason is that, in contrast to other countries, Italian banks often do not judge the creditworthiness of the project, but that of the lender (ENEA 2015; ES 2015).

The importance of the informational, behavioural and organisational barriers of the low priority of energy efficiency (rated the second most important barrier together with access to finance), imperfect information (lack of awareness of investment opportunities) and lack of skilled personnel (internal competences) are also consistent with other research. In industry, the challenge is not so much that firms do not that know their energy costs are high, but their lack of awareness that these costs are a variable that can be managed (ES 2012). To this end, the legislative decree D.Lgs. 102/2014 has introduced mandatory energy audits for large enterprises and energy-intensive companies, as foreseen in the EU Energy Efficiency Directive.

Industrial energy efficiency investments combined with white certificates are generally seen as profitable and low-risk, reflected by the low importance respondents give to the corresponding barriers (average score of 0.19 and 0.13 , respectively). Moreover, although the ESCO certification

\footnotetext{
${ }^{37}$ Although the certificate price has been relatively stable recently - several participants of the FIRE conference stated that they use a certificate price of 100 euros as a rule of thumb for financial calculations - its value is significantly influenced by the savings target. A more ambitious efficiency target means higher marginal compliance costs, while a lower target translates into lower compliance costs and hence a lower market price. As an instable certificate price is a major investment risk, the inexistence of updated targets significantly discourages investments.

38 The ministerial decree DM 28/12/12 announced the publication of new guidelines "within 180 days", i.e. July 2013 (MiSE and MATTM 2012). D.Lgs. 102/2014 of July 2014 spoke again of 180 days (Consiglio dei Ministri 2014). In August 2015, updated guidelines were finally released for public consultation (MiSE and MATTM 2015). Since this process has finished in October 2015, the guidelines have still not been officially published (Giffoni 2016).

${ }^{39}$ To alleviate this problem, the legislative decree 102/2014 has established a 'National Fund for Energy Efficiency' (Fondo nazionale per l'Efficienza Energetica) that will guarantee loans and provide financing for efficiency projects (Consiglio dei Ministri 2014). Although the fund is not operational yet, its introduction is hailed by many experts as an important step to overcome the financial barriers that still restrain energy efficiency investments in Italy (EC JRC 2014; ENEA 2015). Currently, a volume up to 70 million euros per year is being discussed (Re 2015). At the time of writing, however, the fund has not yet been instituted.
} 
is not yet mandatory, a lack of trust in ESCOs does not seem to be a major issue in Italy, at least in the industrial sector. This contrasts with previous empirical studies, where a lack of trust in external actors is often named as an important factor (e.g. EC JRC 2005).

\subsubsection{Drivers for the shift to the industrial sector}

Figure 8 illustrates the drivers for the increase of monitoring plans projects in industry, i.e. more structural projects with a longer technical lifetime and high investment costs, within the last years.

Figure 8: Drivers for energy efficiency measures in the industrial sector

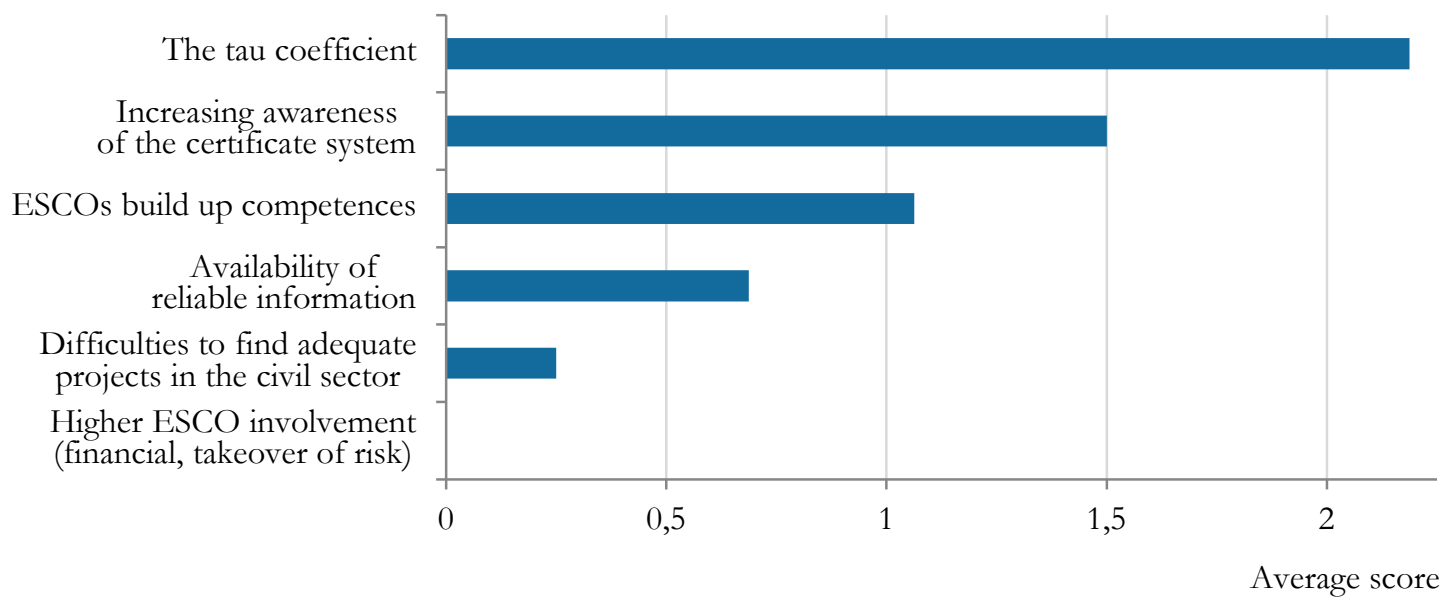

Source: Own illustration

As expected, the major driver behind the shift of energy efficiency investments to the industrial sector is the tau coefficient (average score of 2.2). The tau coefficient has radically transformed the Italian white certificate system by awarding a significantly stronger financial incentive to more long-term projects with high investment costs. The introduction of tau has effectively more than tripled the economic value of white certificates for projects in industry, as the white certificate spot market price has been stable ${ }^{40}$ in recent years and tau typically has a value of 3.36 in industry (project lifetime of 20 years). This has significantly reduced the payback period of these projects by covering a significant share of investment costs (see section 4.1.3). The strength of the financial incentive of white certificates is also reflected by the fact that non-profitability of investments has emerged as a minor investment barrier in the survey (cf. Figure 7).

Informational drivers have also played a key role in the success of the Italian EEO scheme - an increasing awareness of the white certificate scheme is the second most important driver for projects in the industrial sector (average score of 1.5). ${ }^{41}$ This mirrors the fact that informational barriers such as other investment priorities and lack of awareness of investment opportunities have also been ranked as very important (see analysis above). These barriers have been addressed through several channels. First, the mere existence of an incentive mechanism already has an

\footnotetext{
${ }^{40}$ In the 2011-2015 period, the stock market price has remained relatively flat at around 100 euros per certificate. Price data is available for download from GME (2015c).

${ }^{41}$ The importance of informational drivers for energy efficiency policy has also been confirmed by the ENEAConfindustria study mentioned above, where awareness-raising campaigns emerged as the third most important investment driver (ENEA 2015).
} 
informative effect and increases the visibility of energy efficiency projects. ${ }^{42}$ Moreover, companies that take part in the Italian white certificate scheme attract competitors to follow. ${ }^{43}$ Third, organisations such as FIRE and ENEA carry out a whole range of informational activities, such as conferences, workshops, training courses or the publication of frequently asked questions (FAQ) on white certificate project proposals. The availability of information that is reliable has also helped to promote investments (average score of 0.7 ). One explanation is that the process to carry out monitoring plans is much more complex than the standardised deemed savings and simplified monitoring projects that rely on pre-determined technical data sheets. ${ }^{44}$ This complexity had deterred operators from investing into industrial energy efficiency, although the financial incentive of white certificates was already considerable before the introduction of the tan coefficient (Di Santo et al. 2014). ${ }^{45}$

According to the interviewees, a difficulty to find adequate projects in the civil sector has not been a relevant factor behind the shift to the industrial sector (average score of 0.25 ). This is surprising, as one factor responsible for the shift to Italy's industrial sector mentioned in the literature is that projects in the residential sector have become economically less viable due to the fact that white certificates cannot be cumulated anymore with tax deductions and other state incentives since 2013 (Albonico 2013; GSE 2015). Moreover, as discussed above, CFLs were exempted from the scheme in 2011.

Regarding ESCOs, the evidence from the survey is mixed. On the one hand, they are building up competences (average score of 1.1), and this increased expertise supports energy efficiency projects in the industrial sector. In addition to an increased experience from a growing number of projects, one plausible explanation is the mandatory certification process for ESCOs discussed in section 3.3. On the other hand, none of the respondents regards a higher ESCO involvement in terms of project financing or risk sharing as a relevant factor. Thus, given the fact that in 2014 more than 70 percent of white certificates emitted still accrued to energy service provider companies (see Figure 5), it seems that until 2015 only a small fraction of these companies was acting as genuine ESCOs that assist in project financing and share part of the risk. Several interviewees and other participants of the conference belonging to the energy service industry also confirmed that their projects usually do not involve energy performance contracts (EPCs), but traditional forms of contracts such as supply contracts.

\footnotetext{
42 This view was expressed by one of the participants of a stakeholder workshop on behalf of the EU, which took place at the FIRE conference in Rome in March 2015. The workshop was conducted under the Chatham House Rule.

43 This is illustrated, for example, by the case of the first Major Project approved by the Ministry of Economic Development in 2014. The primary competitor of the proponent Italo-NTV, the government-owned railway company Trenitalia, is also considering to apply for a Major Project after the success of NTV's proposal (Leone 2015).

${ }^{44}$ The presentation of a PPPM within the monitoring plans method is complex and requires either the consultation of an external expert (such as an ESCO) or building up internal competences (FIRE 2014).

45 One example of such reliable information is ENEA's regularly updated 'operating guide' (guida operativa) on the white certificate scheme, which explains in detail how the system works and how a successful proposal should be designed (see ENEA 2014). ENEA has also published 'sectoral guidelines' (guide settoriali) to facilitate the presentation of project proposals for monitoring plans (PPPM) in the relevant industrial sectors.
} 


\subsubsection{The effect of white certificates on investment costs and payback time}

According to the interviewees, white certificates typically cover between 20 to 25 per cent of investment costs. ${ }^{46}$ This number is established by two different questions. First, interviewees were asked what fraction of investment costs white certificates typically cover in the industrial sector. The respondents indicated a mean of 21.5 as the average share of investment costs. However, many interviewees found this question difficult to answer and the answers were highly variable. ${ }^{47}$ This high variance of the answers reflects the fact that several respondents stated that the fraction of investment costs covered by the monetary value of white certificates is highly dependent on the project. Hence, a separate question on payback times is used to cross-check this point estimate.

Acceptable payback periods in the Italian industry are typically estimated between two and three years (Di Santo et al. 2014; ES 2012). During the survey, interviewees were asked a) to indicate the maximum payback times that are accepted for industrial energy efficiency investments and b) to specify how this period changes when the monetary value of white certificates is taken into account. The respondents have indicated an average acceptable payback time of 3.12 years (standard deviation of 0.8), which is fully in line with the existing literature. Payback period reduces on average to 2.37 years when white certificates are involved (standard deviation of 0.7 ). This diminution of 0.75 years (or nine months) is an implicit measure of the value of white certificates - it means that white certificates cover 25 per cent of the investment costs. ${ }^{48}$ This confirms the results from the previous question on investment costs, where the average fraction of investment costs covered by white certificates resulted to be 21.5 per cent.

\subsection{Energy services and white certificates}

The Italian white certificates scheme has kick-started the development of an energy services sector. According to the interviewees, for more than half of the ESCOs working in industry above 60 per cent of their projects involve white certificates. Less than ten per cent of the ESCOs have a share below 20 per cent. The ESCO sector has also dramatically grown in size. The number of genuine ESCOs in Italy has increased from five in 2005 to around 100 in $2016 .^{49}$ The total number of Energy Service Businesses (ESCOs and ESPCs) involved in the Italian EEO scheme has increased to 950 in 2015, at a compound annual growth rate of 22 per cent (see Figure 9). These businesses have also delivered the majority of savings in the Italian EEO (cf. Figure 5).

\footnotetext{
${ }^{46}$ This is in line with other sources - according to Valenzano (2015), the average fraction may even be as high as 30 per cent.

47 Only ten out of 16 interviewees responded and in absolute values the answers range from five to 50 per cent, with a sample standard deviation of 14.7 percentage points. Assuming normality of the answers, the 95 per cent confidence interval of the average fraction of investment costs covered lies between 11 and 33 per cent.

48 To verify whether the change in payback period due to white certificates is statistically significant, a one-sided Wilcoxon signed-rank test was carried out. This is a nonparametric equivalent of the paired sample $t$ test that does not rely on any distributional assumptions (Gibbons and Chakraborti 2011). When underlying populations are not normal, such nonparametric tests can be much more efficient than their parametric counterparts (Hollander et al. 2014). The calculations yield a Wilcoxon test statistic $T^{+}=88$ with a corresponding $p$ value of 0.0014 and a 95 per cent lower confidence bound of 0.5 . Thus, there is very strong evidence that white certificates reduce the payback time of investments by at least six months.

49 According to a representative from the Italian regulator AEEGSI.
} 
Figure 9: The number of Energy Service Businesses (SSE) and companies with an Energy Manager active in the Italian white certificate scheme

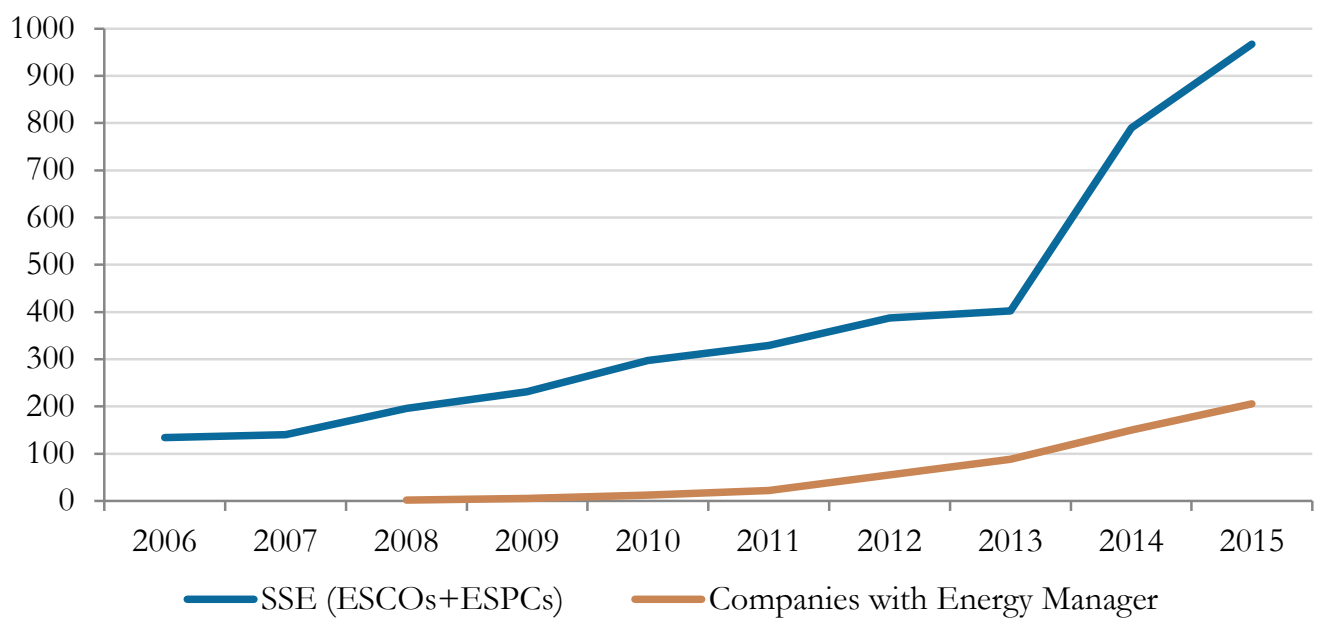

Source: Own illustration using data from AEEG (2007, 2008, 2009a, 2011a, 2012a, 2012c) and GSE (2014a, 2015, 2016)

Mandatory certification of ESCOs, which will become effective in July 2016, has a very positive impact on the development of the ESCO industry (cf. Figure 10). One major problem of the ESCOs solution is that energy service providers often suffer from a lack of credibility and trust, reinforced by the lack of a common definition of energy service companies (EC JRC 2014; Sorrell et al. 2000). The lack of mandatory quality standards in the Italian certificate scheme has also been associated with scarce competences of many energy service providers (Bertoldi et al. 2006). Consequently, the overwhelming majority of respondents in the survey believe that mandatory certification reduces the barrier of imperfect information by building up trust in ESCOs and by facilitating the development of ESCO competences. Mandatory certification might also lead to a greater diffusion of energy performance contracts in the future, as two thirds of Italian ESCOs operating in the industrial sector offer EPCs (ES 2015).

Figure 10: Impact of the mandatory UNI CEI 11352 certification on the ESCO industry
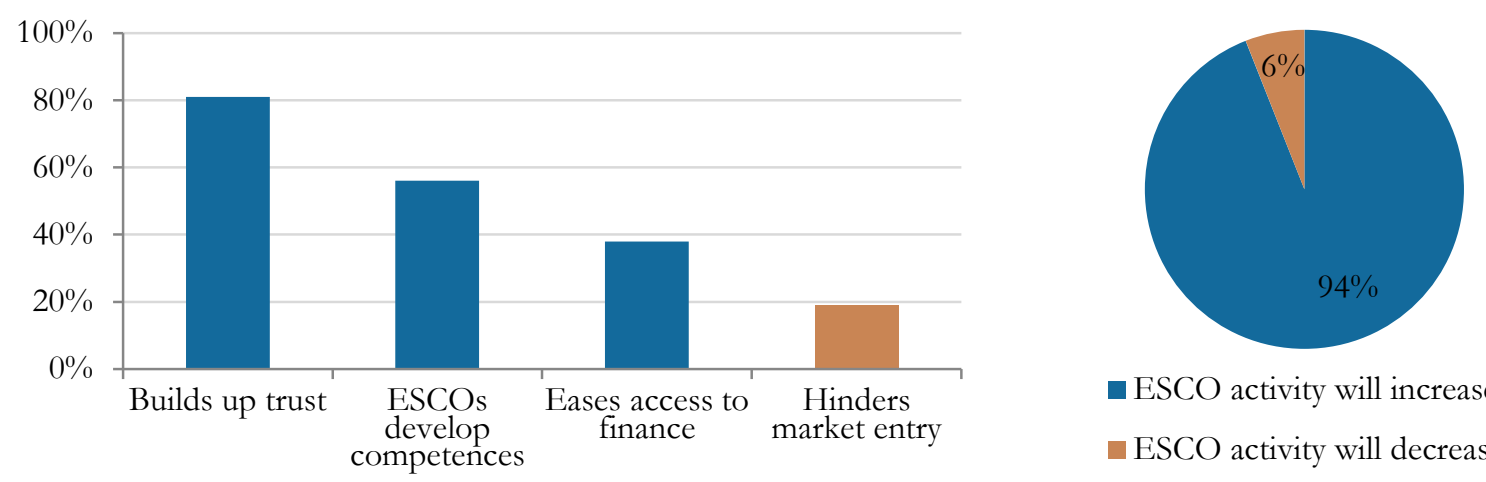

- ESCO activity will increase

ESCO activity will decrease

Source: Own illustration

In parallel to the dynamic development of the Italian energy services sector, a second emerging trend is that an increasing number of companies build up internal energy efficiency competences instead of engaging with external actors. This is reflected in the dynamic increase of companies with an Energy Manager that participate in the white certificate scheme, which has risen to 206 in 2015, up from only 12 in 2010 (cf. Figure 9). This means that already seven per cent of the 3,000 
Italian companies with an Energy Manager use the Italian white certificate scheme. 27 per cent of all white certificates released in 2014 were awarded to such companies. Interestingly, almost half of the companies have named their Energy Manager voluntarily.

\section{Conclusion and outlook}

Despite its difficult start, the Italian white certificate mechanism is a success story. During the initial years energy savings were dominated by compact fluorescent lamps (CFLs) distributed in the 'civil' sector. Whether this has really resulted in genuine energy savings is questionable. CFLs were eventually replaced by a growing number of measures in the industrial sector, peaking at 80 per cent of total certificate emissions in 2013. The survey carried out for this research confirms that the Italian white certificate scheme is now the single most important policy to incentivise energy efficiency in the industrial sector. On a national scale, the mechanism is expected to account for 60 per cent of the Italian energy savings planned until 2020 to comply with the EU Energy Efficiency Directive.

A first policy lesson from the Italian experience is that a meaningful financial incentive is key to incentivise energy efficiency measures with a long lifetime and high upfront investment. This research has revealed that white certificates cover between 20 to 25 per cent of investment costs in the industrial sector. The major driver behind the shift to the industrial sector was the introduction of the tau coefficient, which values energy savings that arise during the entire technical lifetime of an energy efficiency intervention. This improved economic viability of structural projects in the industrial sector is also reflected in a decrease of payback time by around nine months. White certificates or equivalent policy instruments providing a financial incentive can thus make a significant difference in the industrial sector, where projects with a payback period above three years are usually dismissed. Moreover, by increasing awareness the scheme has led to a strong visibility of energy efficiency investment possibilities for industrial companies, helping tackle the market failure of insufficient information.

A second lesson from the Italian white certificate scheme is that energy efficiency obligations are very flexible. Not only are they well-suited to deliver on low-hanging fruit (i.e. cheap, standardisable energy efficiency measures), but can also be designed to deliver more structural interventions in different end-use sectors. Using technical data sheets (deemed savings and simplified monitoring projects in Italy), easily standardisable energy efficiency interventions can be carried out. Via the monitoring plans method, more complicated and project-specific measures can be achieved, combined with a metering of the savings. Uplift factors (applied in Major Projects in Italy) are suitable to foster the large-scale diffusion of innovative technologies, for example in the transport sector. Updating additionality requirements regularly is key to ensuring that white certificate systems only incentivise innovative energy efficiency solutions.

Third, the Italian white certificate mechanism has led to the dynamic development of an energy services sector, comprising now of around 100 active ESCOs. ESCOs step in when industrial companies want to source out energy efficiency interventions and have delivered the vast majority of savings within the Italian system. The evidence collected in the survey shows that ESCOs and other energy service providers have increasingly built up competences due to their involvement in 
the white certificate scheme. The process of developing energy service provider companies (ESPCs) into ESCOs is supported by the obligation to be in possession of the ESCO certification UNI CEI 11352 as a prerequisite to participate in the white certificate scheme, starting from July 2016. The survey has also shown that the mandatory certification process facilitates trust in the ESCOs' competences. White certificate schemes - or other policies supporting the development of an energy services sector - can therefore circumvent the investment barriers of a lack of skilled personnel and imperfect information due to a low trustworthiness of the information source.

Fourth, instead of consulting an external ESCO, the barrier of a lack of skilled personnel can also be addressed by developing internal competences. Italian companies are starting to reap the benefits of the white certificates scheme through their Energy Managers. Almost a third of the white certificates issued now accrue to these businesses. The mandatory certification of Energy Managers as Energy Management Experts will also help elevate the internal competences of these companies. Thus, the long-standing obligation for energy-intensive companies to name an Energy Manager has been put to a more productive use by integrating it into the Italian white certificate scheme.

This illustrates - a fifth lesson from Italy - that effective energy efficiency polices are multidimensional. Energy efficiency investments in the Italian industrial sector are still confined by many businesses' low priority for energy efficiency and insufficient awareness of investment opportunities, for example. The mandatory energy audits for large enterprises and energy-intensive companies introduced by the implementation of the EU Energy Efficiency Directive can be expected to raise awareness that energy costs are a variable that can be managed. Moreover, both businesses and ESCOs are still constrained by a limited access to capital. Consequently, new financial instruments such as soft loans will be key to overcome this barrier.

Lastly, the experience from the Italian white certificates mechanism shows that unambiguous and up-to-date regulation is a crucial prerequisite for the successful implementation of an energy efficiency policy. In Italy, regulatory uncertainty has emerged as the most important barrier to industrial energy efficiency investments. Several factors explain this result, such as the fact that the white certificate guidelines have not been updated since 2011, despite repeated commitments from the relevant authorities.

In sum, energy efficiency obligations can contribute to improve industrial competitiveness by lowering energy costs for businesses, kick-start the development of the energy services industry and foster the transition towards a secure low-carbon economy. Bridging the industrial energy efficiency gap means developing policies tailored to the set of barriers relevant in each national context. EEOs are not the only option to achieve this - public energy efficiency tenders, for example, can serve the same purpose (Langniss and Praetorius 2006). The Italian experience illustrates that the implementation of successful incentives for energy efficiency will likely involve a process of learning and continued evolution of the policies in place. 


\section{References}

Abeyasekera, S., 2003. Quantitative analysis approaches to qualitative data: Why, when and how? Statistical Services Centre, University of Reading. Accessed July 21, 2015, from $<$ http://www.reading.ac.uk/ssc/resources/Docs/Quantitative_analysis_approaches_to_qu alitative_data.pdf>

AEEG, 2012a. Il meccanismo dei Titoli di Efficienza Energetica (certificati bianchi) dal $1^{\circ}$ gennaio al 31 maggio 2012 [The white certificate mechanism from 1 January to 31 May 2012] (No. 434/2012/I/efr). Accessed May 15, 2015, from $<$ http://www.autorita.energia.it/allegati/docs/12/434-12.pdf $>$

AEEG, 2012b. Il meccanismo dei Titoli di Efficienza Energetica (certificati bianchi) dal $1^{\circ}$ giugno al 31 dicembre 2011 [The white certificate mechanism from 1 June to 31 December 2011] (No. 168/2012/I/efr). Accessed May 15, 2015, from $<$ http://www.autorita.energia.it/allegati/docs/12/168-12.pdf>

AEEG, 2012c. Sesto Rapporto Annuale sul meccanismo dei Titoli di efficienza energetica [Sixth annual report about the Italian white certificates] (No. 70/2012/I/efr). Accessed May 15, 2015, from < http://www.autorita.energia.it/allegati/docs/12/070-12.pdf>

AEEG, 2011a. Quinto Rapporto Annuale sul meccanismo dei Titoli di efficienza energetica [Fifth annual report about the Italian white certificates] (No. PAS 7/11). Accessed May 15, 2015, from <http://www.autorita.energia.it/allegati/docs/11/007-11pas.pdf $>$

AEEG, 2011b. Il meccanismo dei Titoli di Efficienza Energetica (certificati bianchi) dal $1^{\circ}$ giugno al 31 dicembre 2010 [The white certificate mechanism from 1 June to 31 December 2010] (No. PAS 9/11). Accessed June 4, 2015, from <http://www.autorita.energia.it/allegati/segnalazioni/009-11 pas.pdf>

AEEG, 2011c. Il meccanismo dei Titoli di Efficienza Energetica (certificati bianchi) dall' $1^{\circ}$ gennaio al 31 maggio 2011 [The white certificate mechanism from 1 January to 31 May 2011] (No. PAS 18/11). Accessed June 4, 2015, from <http://www.autorita.energia.it/allegati/segnalazioni/018-11pas.pdf>

AEEG, 2011d. Delibera EEN 9/11 (Linee guida) [Delibera EEN 9/11 (Guidelines)]. Accessed July 23, 2015, from <http://www.autorita.energia.it/it/docs/11/009-11een.htm>

AEEG, 2010a. Il meccanismo dei Titoli di Efficienza Energetica (certificati bianchi) dal $1^{\circ}$ giugno al 31 dicembre 2009 [The white certificate mechanism from 1 June to 31 December 2009]. Accessed June 4, 2015, from $<$ http://www.autorita.energia.it/allegati/pubblicazioni/2sem2009TEE.pdf>

AEEG, 2010b. Il meccanismo dei Titoli di Efficienza Energetica (certificati bianchi) dall' $1^{\circ}$ gennaio al 31 maggio 2010 [The white certificate mechanism from 1 January to 31 May 2010]. Accessed June 4, 2015, from $<$ http://www.autorita.energia.it/allegati/pubblicazioni/1 sem2010TEE.pdf>

AEEG, 2009a. Quarto Rapporto Annuale sul meccanismo dei Titoli di efficienza energetica [Fourth annual report about the Italian white certificates]. Accessed June 4, 2015, from $<$ http://www.autorita.energia.it/allegati/pubblicazioni/eerapporto_09.pdf>

AEEG, 2009b. Il meccanismo dei Titoli di Efficienza Energetica dal $1^{\circ}$ giugno al 31 dicembre 2008 [The white certificate mechanism from 1 June to 31 December 2008]. Accessed June 4, 2015, from < http://www.autorita.energia.it/allegati/pubblicazioni/semTEE2008.pdf> 
AEEG, 2009c. Il meccanismo dei Titoli di Efficienza Energetica dall'1 $1^{\circ}$ gennaio al 31 maggio 2009 [The white certificate mechanism from 1 January to 31 May 2009]. Accessed June 4, 2015, from < http://www.autorita.energia.it/allegati/pubblicazioni/1semTEE2009.pdf>

AEEG, 2008. Terzo Rapporto Annuale sul meccanismo dei Titoli di efficienza energetica [Third annual report about the Italian white certificates]. Accessed June 4, 2015, from $<$ http://www.autorita.energia.it/allegati/pubblicazioni/eerapporto_08.pdf>

AEEG, 2007. Secondo Rapporto Annuale sul meccanismo dei Titoli di efficienza energetica [Second annual report about the Italian white certificates]. Accessed June 4, 2015, from <http://www.autorita.energia.it/allegati/pubblicazioni/rapporto_07.pdf>

AEEG, 2006. Primo Rapporto Annuale sul meccanismo dei Titoli di efficienza energetica [First annual report about the Italian white certificates]. Accessed June 4, 2015, from $<$ http://www.autorita.energia.it/allegati/pubblicazioni/rapporto_06.pdf>

AEEGSI, 2014. Stato e prospettive del meccanismo dei Titoli di efficienza energetica [Status and prospectives of the white certificate mechanism] (No. 337/2014/I/efr). Autorità per l'energia elettrica il gas e il sistema idrico. Accessed May 14, 2015, from $<$ http://www.autorita.energia.it/allegati/docs/14/337-14.pdf >

Albonico, V., 2013. Il punto di vista delle ESCo rappresentate da Agesi sul meccanismo dei Certificati Bianchi e sul D.M. 28/12/2012 [The point of view of the ESCOs represented by Agesi on the white certificate mechanism and the DM 28/12/12]. Gestione Energia 1/2013, 23-24.

Ancora, M., 2013. Le novità sui Certificati Bianchi [The novelties about the white certificates]. Gestione Energia 1/2013, 6-7.

Backlund, S., Thollander, P., 2011. The energy service gap: What does it mean?, in: Eceee 2011 Summer Study Proceedings - Energy Efficiency First: The Foundation of a Low-Carbon Society. pp. 649-656. Accessed April 20, 2015, from $<$ http://proceedings.eceee.org/papers/proceedings2011/3-

081_Backlund.pdf?returnurl=http $\% 3 \mathrm{~A} \% 2 \mathrm{~F} \% 2$ Fproceedings.eceee.org $\% 2$ Fvisabstrakt.php $\% 3$ Fevent $\% 3$ D $1 \% 26$ doc $\% 3$ D3-081-11>

Belcastro, F., 2014. La certificazione delle ESCO e degli EGE [The certification of ESCOs and EGE]. Accessed June 22, 2015, from <http://pressroom.fire-italia.org/wpcontent/uploads/2014/10/2014-10-fiera-VR.pdf>

Bertoldi, P., Labanca, N., Rezessy, S., Steuwer, S., Oikonomou, V., 2013. Where to place the saving obligation: Energy end-users or suppliers? Energy Policy 63, 328-337.

Bertoldi, P., Rezessy, S., Lees, E., Baudry, P., Jeandel, A., Labanca, N., 2010. Energy supplier obligations and white certificate schemes: Comparative analysis of experiences in the European Union. Energy Policy 38, 1455-1469.

Bertoldi, P., Rezessy, S., Vine, E., 2006. Energy service companies in European countries: Current status and a strategy to foster their development. Energy Policy 34, 1818-1832.

Cagno, E., Trianni, A., 2014. Evaluating the barriers to specific industrial energy efficiency measures: an exploratory study in small and medium-sized enterprises. Journal of Cleaner Production 82, 70-83.

Consiglio dei Ministri, 2014. Decreto legislativo 4 luglio 2014, n.102 [Legislative decree 4 July 2014, n.102]. Accessed March 7, 2016, from <http://www.gazzettaufficiale.it/eli/id/2014/07/18/14G00113/sg> 
Di Santo, D., Biele, E., D’Ambrosio, S., Forni, D., Tomassetti, G., 2014. Italian white certificates scheme: the shift toward industry, in: Eceee 2014 Industrial Summer Study Proceedings Retool for a Competitive and Sustainable Industry. Papendal, Arnhem, the Netherlands, pp. 19-30.

EC, 2015. Energy Union Package - A Framework Strategy for a Resilient Energy Union with a Forward-Looking Climate Change Policy, $\operatorname{COM}(2015) 80$ final. European Commission. Accessed March 16, 2016, from <http://eurlex.europa.eu/resource.html?uri=cellar:1bd46c90-bdd4-11e4-bbe1-

01aa75ed71a1.0001.03/DOC_1\&format=PDF>

EC JRC, 2014. The European ESCO Market Report 2013 (No. EUR 26691 EN), JRC Science and Policy Reports. European Commission - Joint Research Centre. Accessed April 22, 2015, from <http://bookshop.europa.eu/en/the-european-esco-market-report-2013pbLDNA26691/downloads/LD-NA-26691-EN-

N/LDNA26691ENN_002.pdf?FileName=LDNA26691ENN_002.pdf\&SKU=LDNA26 691ENN_PDF\&CatalogueNumber=LD-NA-26691-EN-N>

EC JRC, 2005. Energy service companies in Europe - Status report 2005 (No. EUR 21646 EN), JRC Science and Policy Reports. European Commission - Joint Research Centre. Accessed April 22, 2015, from <http://bookshop.europa.eu/en/energy-services-companies-ineurope-pbLBNA21646/downloads/LB-NA-21646-EN-

C/LBNA21646ENC_002.pdf?FileName=LBNA21646ENC_002.pdf\&SKU=LBNA2164 6ENC_PDF\&CatalogueNumber=LB-NA-21646-EN-C>

Ecofys, 2012. Measurement, Verification and Additionality of Electricity Demand Reductions. Accessed July 21, 2015, from <https://www.gov.uk/government/uploads/system/uploads/attachment_data/file/66216 /Electricity_demand_reduction__measurement_verification_and_additionality.pdf $>$

ENEA, 2015. Rapporto Annuale Efficienza Energetica 2015 [Annual Energy Efficiency Report 2015]. Accessed July 1, 2015, from <http://www.enea.it/it/produzione-scientifica/pdfvolumi/raee-2015.pdf>

ENEA, 2014. Ottenere i titoli di efficienza energetica - Guida operativa 3.1 [Obtaining white certificates - Operating guide 3.1]. Accessed May 11, 2015, from $<$ http://www.enea.it/it/produzione-scientifica/pdfvolumi/CertificatiBianchiluglio2014.pdf $>$

ENEA, 2013. Analisi delle Proposte di Progetto e Programma di Misura (PPPM) 2005-2012 [Analysis of the PPPM 2005-2012]. Accessed March 29, 2016, from <http://www.fireitalia.org/prova/wp-content/uploads/2014/03/Analisi-delle-proposte-di-progetto-eprogramma-di-misura-PPPM-dei-certificati-bianchi-2005-2012.pdf>

ENEA, 2011. I titoli di efficienza energetica - Guida operativa [White certificates - Operating guide]. Accessed March 29, 2016, from <http://www.itaca.org/documenti/news/Certificatibianchi2011.pdf>

EnergyINlink, 2014. Lista delle ESCO certificate secondo la norma UNI CEI 11352 [List of ESCOs certified according to the norm UNI CEI 11352] [WWW Document]. Accessed June 5, 2015, from <http://www.energyinlink.it/news/2012/07/lista-delle-escocertificate $/>$

ENSPOL, 2016. Report on existing and planned EEOs in the EU - Part II: Description of planned schemes. Accessed March 16, 2016, from 
$<$ http://enspol.eu/sites/default/ files/results/D2.1.1\%20Report $\% 20$ on $\% 20$ existing $\% 20$ an d $\% 20$ planned $\% 20$ EEOs $\% 20$ in $\% 20$ the $\% 20$ EU $\% 20$ -

$\% 20$ Part $\% 20 \mathrm{II} \% 20$ Description $\% 20$ of $\% 20$ planned $\% 20$ schemes.pdf $>$

ENSPOL, 2015. Report on existing and planned EEOs in the EU - Part I: Evaluation of existing schemes. Accessed March 16, 2016, from $<$ http://enspol.eu/sites/default/ files/results/D2.1.1\%20Report $\% 20$ on $\% 20$ existing $\% 20$ an d $\% 20$ planned $\% 20$ EEOs $\% 20$ in $\% 20$ the $\% 20$ EU $\% 20$ -

$\% 20$ Part $\% 201 \% 20$ Evaluation $\% 20$ of $\% 20$ existing $\% 20$ schemes.pdf $>$

EP, 2012. Directive 2012/27/EU of the European Parliament and of the Council of 25 October 2012 on energy efficiency, amending Directives 2009/125/EC and 2010/30/EU and repealing Directives 2004/8/EC and 2006/32/EC. Accessed July 21, 2015, from $<$ http://eur-lex.europa.eu/legalcontent/EN/TXT/PDF/?uri=CELEX:32012L0027\&from=en>

ES, 2015. Energy Efficiency Report - $5^{\circ}$ edizione. [Energy Efficiency Report - 5th edition]. Energy \& Strategy Group, Politecnico di Milano. Accessed from $<$ http://www.energystrategy.it/report/eff.-energetica.html>

ES, 2012. Energy Efficiency Report - $2^{\circ}$ edizione. Energy Efficiency Report - 2nd edition]. Energy \& Strategy Group, Politecnico di Milano. Accessed July 2, 2015, from $<$ http://www.energystrategy.it/report/eff.-energetica.html>

Eurostat, 2015a. Energy production and imports [WWW Document]. Accessed June 13, 2016, from $<$ http://ec.europa.eu/eurostat/statisticsexplained/index.php/Energy_production_and_imports $>$

Eurostat, 2015b. Electricity price statistics [WWW Document]. Accessed March 16, 2016, from $<$ http://ec.europa.eu/eurostat/statistics-explained/index.php/Electricity_price_statistics>

Eurostat, 2014. Energy, transport and environment indicators - 2014 edition. Publications Office of the European Union, Luxembourg. Accessed July 14, 2015, from $<$ http://ec.europa.eu/eurostat/documents/3930297/6613266/KS-DK-14-001-ENN.pdf $>$

FIRE, 2016. Elenco delle ESCO certificate UNI CEI 11352 [List of ESCOs certified UNI CEI 11352] [WWW Document]. Accessed March 1, 2016, from <http://www.fireitalia.org/elenco-delle-esco-certificate-uni-cei-11352/>

FIRE, 2015. Osservazioni FIRE in occasione della consultazione sull'aggiornamento delle linee guida nel meccanismo dei certificati bianchi [Observations of FIRE on the consultation of the update of the white certificate guidelines]. Accessed March 8, 2016, from $<$ https://www.senato.it/application/xmanager/projects/leg17/attachments/documento_e vento_procedura_commissione/files/000/003/106/2015_10_02_-_FIRE.pdf>

FIRE, 2014. I certificati bianchi: Uno strumento di competitività per le imprese [White certificates: An instrument of competitiveness for businesses]. Federazione Italiana per l'uso Razionale dell'Energia. Accessed May 14, 2015, from <http://www.fire-italia.it/pubblicazioni/201404_guida_TEE_completa.pdf>

Gibbons, J.D., Chakraborti, S., 2011. Nonparametric Statistical Inference, 5th edition. ed. Chapman and Hall/CRC, Boca Raton.

Giffoni, M.A., 2016. Certificati Bianchi, calo dei progetti e sempre più industria [White Certificates, decrease of projects and ever more industry]. Nextville. Accessed March 7, 2016, from $<$ http://www.nextville.it/news/2373> 
Giliberto, J., 2015. L'energy manager taglia la bolletta (ma nella Pa spesso non è nominato) [The Energy Manager cuts the bill (but is often not appointed in public administration)]. Il Sole 24 Ore. Accessed July 5, 2015, from <http://pressroom.fire-italia.org/wpcontent/uploads/2015/04/sole24ore_28aprile2015.jpg>

Giraudet, L.-G., Finon, D., 2015. European experiences with white certificate obligations: A critical review of existing evaluations. Economics of Energy \& Environmental Policy 4.

GME, 2016. Mercato dei TEE - II semestre 2015 [White certificate market - 2nd semester 2015]. Accessed March 9, 2016, from <https://www.mercatoelettrico.org/It/MenuBiblioteca/documenti/20150203MercatoDei TitolidiEfficienzaEnergeticaIIsemestre2015.pdf>

GME, 2015a. Mercato dei TEE - II semestre 2014 [White certificate market - 2nd semester 2014]. Accessed July 9, 2015, from <http://www.mercatoelettrico.org/IT/MenuBiblioteca/documenti/20150202RapportoTE E_II_semestre2014.pdf>

GME, 2015b. Mercato dei TEE - I semestre 2015 [White certificate market - 1st semester 2015]. Accessed March 9, 2016, from $<$ https://www.mercatoelettrico.org/It/MenuBiblioteca/documenti/20150730MercatodeiT itolidiEfficienzaEnergeticaIsemestre2015.pdf>

GME, 2015c. White Certificates Stock Market Data. Accessed July 3, 2015, from $<$ http://www.mercatoelettrico.org/It/download/DownloadDati.aspx?val=TEE_SINTESI TEE>

GME, 2014a. Mercato dei TEE - I semestre 2014 [White certificate market - 1st semester 2014]. $\begin{array}{llll}\text { Accessed July } & 9, & \text { 2015, }\end{array}$ <http://www.mercatoelettrico.org/IT/MenuBiblioteca/documenti/20140721TitoliEfficie nzaEnergetica_I_semestre2014.pdf $>$

GME, 2014b. Mercato dei TEE - II semestre 2013 [White certificate market - 2nd semester 2013]. Accessed July 9, 2015, from <http://www.mercatoelettrico.org/IT/MenuBiblioteca/documenti/20140130RapportoSe mestreII_2013_TEE.pdf $>$

GME, 2013a. Mercato dei TEE - I semestre 2013 [White certificate market - 1st semester 2013]. Accessed July 9, 2015, from <http://www.mercatoelettrico.org/IT/MenuBiblioteca/documenti/20130722TitoliEfficie nzaEnergetica-1 semestre2013.pdf>

GME, 2013b. Mercato dei TEE - II semestre 2012 [White certificate market - 2nd semester 2012]. Accessed July 9, 2015, from $<$ http://www.mercatoelettrico.org/IT/MenuBiblioteca/documenti/20130128RapportoTE E.pdf $>$

GME, 2012a. Mercato dei TEE - I semestre 2012 [White certificate market - 1st semester 2012]. Accessed July 9, 2015, from $<$ http://www.mercatoelettrico.org/IT/MenuBiblioteca/documenti/20120717RapportoTE E.pdf $>$

GME, 2012b. Mercato dei TEE - II semestre 2011 [White certificate market - 2nd semester 2011]. Accessed July $2015, \quad$ from $<$ http://www.mercatoelettrico.org/IT/MenuBiblioteca/documenti/20120113MercatoTitol iEfficienzaEnergeticaIIsemestre.pdf $>$ 
GME, 2011. Mercato dei TEE - I semestre 2011 [White certificate market - 1st semester 2011]. Accessed March 9, 2016, from $<$ https://www.mercatoelettrico.org/It/MenuBiblioteca/documenti/20110713RapportoTE E_I_semestre11.pdf $>$

Grubb, M., Hourcade, J.-C., Neuhoff, K., 2014. Planetary Economics: Energy, climate change and the three domains of sustainable development. Routledge, New York.

GSE, 2016. Rapporto Annuale sul meccanismo dei Certificati Bianchi 2015 [Annual report about the white certificate mechanism 2015]. Accessed March 9, 2016, from $<$ http://www.gse.it/it/CertificatiBianchi/GSE_Documenti/Documenti/Rapporto\%20an nuale $\% 20$ CB $\% 202015 \_F I N A L \_01 . p d f>$

GSE, 2015. Rapporto Annuale sul meccanismo dei Certificati Bianchi 2014 [Annual report about the white certificate mechanism 2014]. Accessed June 1, 2015, from $<$ http://www.gse.it/it/CertificatiBianchi/GSE_Documenti/Documenti/Rapporto $\% 20$ An nuale $\% 20$ Certificati $\% 20$ Bianchi_final.pdf $>$

GSE, 2014a. Rapporto Annuale sul meccanismo dei Certificati Bianchi 2013 [Annual report about the white certificate mechanism 2013]. Accessed May 14, 2015, from $<$ http://www.gse.it/it/CertificatiBianchi/GSE_Documenti/Documenti/Rapporto\%20An nuale $\% 20$ sul $\% 20$ meccanismo $\% 20$ dei $\% 20$ Certificati $\% 20$ Bianchi.pdf $>$

GSE, 2014b. Esito dell'attività istruttoria tecnico-economica sul grande progetto "la realizzazione della nuova flotta ad alta velocità Italo" [Outcome of the technno-economic evaluation on the Major Project "the realisation of the new fleet of high-speed trains Italo"]. Accessed July 18, 2015, from <http://www.sviluppoeconomico.gov.it/images/stories/normativa/Decreto_interministeri ele_1dicembre2014_Italo_Istruttoria.pdf>

Hansen, S.J., 2006. Performance contracting: expanding horizons. The Fairmont Press, Lilburn, GA.

Hansen, S.J., Langlois, P., Bertoldi, P., 2009. ESCOs around the world: Lessons learned in 49 countries. The Fairmont Press, Lilburn, GA.

Hollander, M., Wolfe, D.A., Chicken, E., 2014. Nonparametric Statistical Methods, Third edition. ed. Wiley, Hoboken, New Jersey.

Iannaccone, S., 2015. Compagnie ferroviarie, "per Italo un regalo da 18 milioni di euro" [Railway companies, "a present of 18 million euros for Italo"]. Il Fatto Quotidiano. Accessed July 18, 2015, from <http://www.ilfattoquotidiano.it/2015/02/19/compagnie-ferroviarie-peritalo-regalo-18-milioni/1438033/>

IEA, 2012. World Energy Outlook 2012. Organisation for Economic Co-operation and Development, Paris.

Jaffe, A.B., Stavins, R.N., 1994. The energy-efficiency gap: What does it mean? Energy Policy 22, 804-810.

Langniss, O., Praetorius, B., 2006. How much market do market-based instruments create? An analysis for the case of "white" certificates. Energy Policy 34, 200-211.

Lees, E., 2016. Toolkit for Energy Efficiency Obligations. Regulatory Assistance Project (RAP). Accessed March 16, 2016, from $<$ http://www.raponline.org/document/download/id/8029> 
Lees, E., 2012. Energy efficiency obligations - the EU experience. Eceee briefing for DG Energy on EU energy efficiency obligations. Eoin Lees Energy. Accessed May 6, 2015, from $<$ http://www.eceee.org/policy-areas/EE-directive/energy-efficiency-obligations>

Legge 10, 1991. Legge 9 gennaio 1991, n. 10. Accessed July 21, 2015, from <http://www.normattiva.it/uri-res/N2Ls?urn:nir:stato:legge:1991-01-09;10!vig=>

Leone, L., 2015. Adesso anche Trenitalia vuole i certificati bianchi [Now also Trenitalia wants the white certificates]. Milano Finanza. Accessed July 3, 2015, from $<$ http://www.lestradedellinformazione.it/contents/instance1/files/document/4330Rasseg nastampa-m.pdf>

MiSE, 2014. NEEAP 2014 - Italian Energy Efficiency Action Plan. Ministry of Economic Development. Accessed May 13, 2015, from <http://ec.europa.eu/energy/sites/ener/files/documents/2014_neeap_en_italy.pdf>

MiSE, MATTM, 2015. Consultazione Pubblica - Proposte per il potenziamento e la qualifica del meccanismo dei Certificati Bianchi [Public Consultation - Proposals for a strengthening and the role of the white certificate mechanism]. Ministry of Economic Development / Ministry of the Environment. Accessed March 7, 2016, from $<$ http://www.sviluppoeconomico.gov.it/images/stories/documenti/Proposte_aggiorname nto_meccanismo_CB.pdf $>$

MiSE, MATTM, 2013. Italy's National Energy Strategy: for a more competitive and sustainable energy. Ministry of Economic Development / Ministry of the Environment. Accessed April 14, 2015, from $<$ http://www.sviluppoeconomico.gov.it/images/stories/documenti/SEN_EN_marzo201 3.pdf>

MiSE, MATTM, 2012. Decreto ministeriale 28 dicembre 2012 [Ministerial decree 28 December 2012]. Accessed July 22, 2015, from $<$ http://www.sviluppoeconomico.gov.it/images/stories/normativa/DM_Certificati_bianc hi_28_dicembre_2012.pdf>

Pavan, M., 2012. Tradable white certificates: experiences and perspectives. Energy Efficiency 5, 8385.

Re, L., 2015. Le strategie del governo per sbloccare gli investimenti in efficienza energetica [The government's strategy to release investments into energy efficiency]. Qualenergia. Accessed July 2, 2015, from <http://www.qualenergia.it/articoli/20150422-le-strategie-del-governoper-sbloccare-gli-investimenti-in-efficienza-energetica>

Romano, S., 2013. Nuovo decreto Certificati Bianchi: finalità e obiettivi [New white certificate decree: puropose and objectives]. Gestione Energia 1/2013, 21-22.

Schleich, J., 2009. Barriers to energy efficiency: A comparison across the German commercial and services sector. Ecological Economics, Methodological Advancements in the Footprint Analysis 68, 2150-2159.

Sorrell, S., 2007. The economics of energy service contracts. Energy Policy 35, 507-521.

Sorrell, S., Schleich, J., Scott, S., O’Malley, E., Trace, F., Boede, U., Ostertag, K., Radgen, P., 2000. Reducing barriers to energy efficiency in public and private organizations. Accessed February 23, 2015, from <http://www.sussex.ac.uk/Units/spru/publications/reports/barriers/final.html> 
Stavins, R.N., 2003. Experience with market-based environmental policy instruments, in: Mäler, K.G., Vincent, J.R. (Eds.), Handbook of Environmental Economics. Elsevier, Amsterdam, The Netherlands, pp. 355-435.

Thollander, P., Backlund, S., Trianni, A., Cagno, E., 2013. Beyond barriers - A case study on driving forces for improved energy efficiency in the foundry industries in Finland, France, Germany, Italy, Poland, Spain, and Sweden. Applied Energy 111, 636-643.

Thollander, P., Palm, J., 2013. Improving Energy Efficiency in Industrial Energy Systems. Springer London, London.

Trianni, A., Cagno, E., 2012. Dealing with barriers to energy efficiency and SMEs: some empirical evidences. Energy 37, 494-504.

Trianni, A., Cagno, E., Worrell, E., Pugliese, G., 2013. Empirical investigation of energy efficiency barriers in Italian manufacturing SMEs. Energy 49, 444-458.

Valenzano, D., 2015. Titoli di Efficienza Energetica: il funzionamento del meccanismo e i risultati raggiunti [White certificates: the mode of operation and the results achieved]. Gestione Energia 1/2015, 18-20. 